This report was prepared as an account of Government sponsored work. Neither the United States, nor the Commission, nor any person acting on behalf of the Commission:

A. Makes any warranty or representation, express or implied, with respect to the accurcacy, completeness, or usefulness of the intormation contrined in this report, or that the use of any information, apparatus, method, or process disclosed in this report may not infringe privately owned rights; or

B. Assumes any liabilities with respect to the use of, or for damages resulting from the use of any information apparatus, method, or process disclosed in this report.

As used in the above, "person acting on behalf of the Commission" includes any employee or coniractior of the Commission to the extent that such employee or contractor prepares, handles or distributes, or provides access to, any information pursuant to his employment or contract with the Commission.

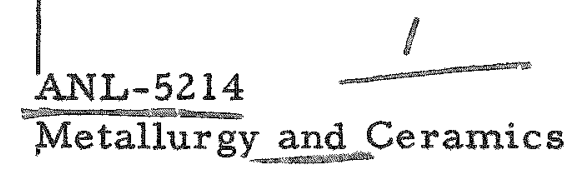

\author{
ARGONNE NATIONAL LABORATORY \\ P. O. Box 299 \\ Lemont, Illinois
}

\title{
DIMENSIONAL STABILITY OF URANIUM POWDER COMPACTS UPON THERMAL CYCLING
}

by

R. M. Mayfield, S. T. Zegler and H. H. Chiswik

Price $\$ 0.35$

November 30,1953

Available from the

Office of Technical Services

Department of Commerce

Washington 25, D. C.

Final Report - Metallurgy Program 5.1.10

Portions of the material in this report have appeared in the following Metallurgy Division Quarterly Reports:

ANL Number

Date

Page

4316

4399

4508 .

4580

4655

4736

4784

4923

4966
Jan., Feb., Mar. 1949
Oct., Nov,, Dec. 1949
Apr., May., June 1950
July, Aug., Sept. 1950
Jan., Feb., Mar. 1951
July, Aug., Sept. 1951
Oct., Nov., Dec. 1951
July. Aug., Sept. 1952
Oct., Nov, Dec. 1952
$42-48$

$72-74$

$58-59$

$45-51$

$85-86$

$33-38$

$30-31$

$110-111$

$57-58$

Operated by The University of Chicago

under

Contract W-31-109-eng-38 


\section{DISCLAIMER}

This report was prepared as an account of work sponsored by an agency of the United States Government. Neither the United States Government nor any agency Thereof, nor any of their employees, makes any warranty, express or implied, or assumes any legal liability or responsibility for the accuracy, completeness, or usefulness of any information, apparatus, product, or process disclosed, or represents that its use would not infringe privately owned rights. Reference herein to any specific commercial product, process, or service by trade name, trademark, manufacturer, or otherwise does not necessarily constitute or imply its endorsement, recommendation, or favoring by the United States Government or any agency thereof. The views and opinions of authors expressed herein do not necessarily state or reflect those of the United States Government or any agency thereof. 


\section{DISCLAIMER}

Portions of this document may be illegible in electronic image products. Images are produced from the best available original document. 
TABLE OF CONTENTS

Page

I. INTRODUCTION ..................... 6

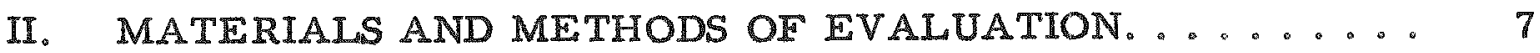

III. RESULTS ....................... 8

1. Cold Compacted and Sintered Specinens ....... 8

2. Cold Compacted, Sintered, Repressed and Annealed Specimens.................. 8

3. Hot Pressed Specimens Made From Uranium Powders ......................... 9

4. Hot Pressed Specimens Made From Uxanium Hydride Powders............... 11

5. Effects of Cycling Variables ............ 13

IV. DISCUSSION OF RESULTS .............. 14

v. CONCIUSIONS ..................... 16

VI. BIBLIOGRAPHY ................... 16 


\section{LIST OF TABLES}

Table

Title

Page

I Fabrication Data of Specimens Made from

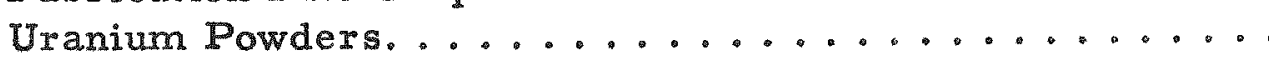

II Fabrication Data of Specimens Made Dixectly

from Uranium Hydride Powders ...............

III Thermal Cycling Data of Specimens Made from Uranium Powders.....................

IV Thermal Cycling Data of Specimens Made from

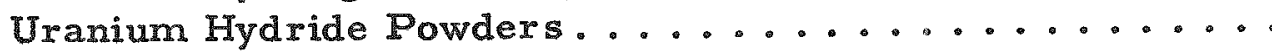


LIST OE FIGURES

Figure

Title

Page

1 Surface Appearance of Compacts U-34 A, B, C and E After Woosher Cycling Between $50^{\circ} \mathrm{C}$ and $600^{\circ} \mathrm{C} \ldots 17$

2 Microstructure of Specimen U34-C Before Cycling...... 17

3 Porosity in Specimen U34-C Before Cycling ........ 18

4 Surface Appearance of Compacts $76 \mathrm{~B}-1$ and 2 After 500 Woosher Cycles ................. 18

5 Porosity of Specimen 76B-2 Before Cycling ........ 19

6 Surface Appearance of Compacts 168-1 and 2 After 200 Woosher Cycles ................. 19

7 Surface Appearance of Hot Pressed Compacts 509-1 and 510-1 After 500 Woosher Cycles........ 20

8 Microstructure of Hot Pressed Compact 510-1 After 500 Woosher Cycles.............. 20

9 Microstructure of Beta Treated Hot Pressed Compact 509-1 After 500 Woosher Cycles..........

10 Surface Appearance of Beta Treated Hot Pressed Compacts After 500 Woosher Cycles ........

11 Surface Appearance of Rolled and Beta Treated Rods After 500 Woosher Cycles ...............

12 Surface Appearance of Hot Pressed Compacts $611-1$ through 7 After 500 Woosher Cycles.........

13 Surface and End Appearances of Compacts Nos.

671,673 and 674 After 250 Induction Cycles

Between $100^{\circ} \mathrm{C}$ and $550^{\circ} \mathrm{C} \ldots \ldots \ldots$

14 Surface Appearance of Compacts Nos.1359, 1392,

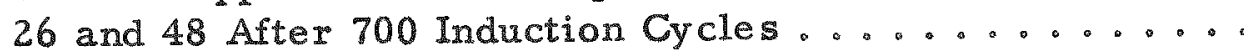

15 Surface Appearance of Compacts Nos. 645 and 651

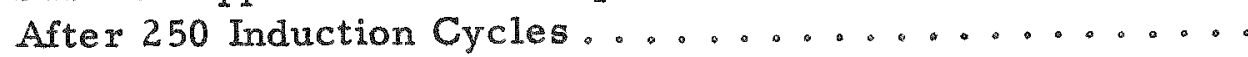

16 Surface Appearance of Hot Pressed Compacts Nos.

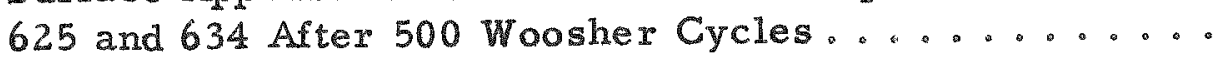

17 Surface Appearance of 4 " Long Sinterwelded Compact

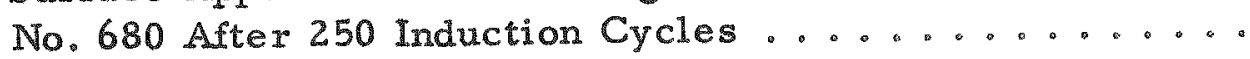

18 Surface Appearance of Beta Treated Rolled Uranium Rod and Sinterwelded Compact No.696 After 700

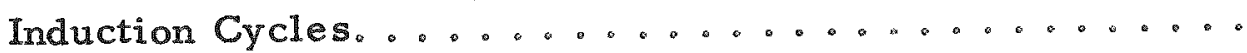




\title{
DIMENSIONAL STABILITY OF URANIUM POWDER COMPACTS UPON THERMAL CYCLING
}

\author{
by \\ R.M.Mayfield, S. T。 Zegler and $H$. H。Chiswik
}

\section{INTRODUCTION}

Thermal cycling tests $(1) *$ on uranium have shown that the dimensional changes that occur on cycling in the alpha range are directly related to both the texture of the material and its grain size: cold rolled rods generally elongate in the direction of rolling, while the same rods, after a betatreatment, ** grow at rates several orders of magnitude lower. This considerable improvement by beta-treatment has been attributed to the texture randomization accompanying the heat-treatment. In the course of this heattreatment, however, considerable grain growth occurs, which has the effect of causing surface roughening on cycling (also referred to as "bumping"); fine grained material generally retains a smooth surface. These observations led to the speculation that the most desirable structure in uranium, from standpoint of dimensional stability, is one that combines both a random texture and a fine grain size. Heat treatment of rolled rod offered no easy method to obtain such a product; powder metallurgical techniques, however, appeared ideally suited for this purpose.

To this end, early in 1949, the Sylvania Electric Products Company initiated a program to develop suitable techniques for producing uranium powder compacts having the above-mentioned desired characteristics. Because of the availability of thermal cycling equipment at Argonne, the MetalIurgy Division of the Laboratory has undertaken to evaluate the stability of the various experimental compacts produced in the developmental phases of the program. This report contains the results of these evaluations.

* Numbers in parenthesis refer to bibliography at end of report. **water quenching from beta phase; about $725^{\circ} \mathrm{C}$. 


\section{MATERIALS AND METHODS OF EVALUATION}

The compacts made available for stability evaluation were prepared by one of the following methods:

1. Cold compacting and sintering at temperatures in the high gamma range $-1095^{\circ}$ to $1120^{\circ} \mathrm{C}$.

2. Cold compacting, sintering, repressing, and final annealing either in the alpha range or the gamma range.

3. Hot pressing in the high alpha temperature range.

These methods have been described in detail by Sylvania, $(2,3)$ and will not be described here. Tables I and II contain summaries of the pertinent fabrication details as supplied by Sylvania, such as the raw materials and powder sizes used, and the pressing, sintering and annealing variables. The densities of the compacts ranged from 16.2 to $18.92 \mathrm{gms} / \mathrm{cc}$, with the higher values attained in the hot pressed compacts. The grain sizes of the sintered specimens were very large and irregular: the hot pressed compact grains were uniformly fine with average diameters less than $0.025 \mathrm{~mm}$.

The dimensional stability of the materials were evaluated from the results obtained upon the rmal cycling in either the vertical tube (Woosher) or induction cycling units. (4) The cycling temperature limits in the Woosher were $50^{\circ} \mathrm{C}$ and $600^{\circ} \mathrm{C}$, using a 5 second transfer time on heating and cooling and a 5 minute holding time at each temperature. In the induction cycling unit the temperature limits were $100^{\circ} \mathrm{C}$ and $550^{\circ} \mathrm{C}$, the heating time 10 to 12 minutes, and the cooling time 25 to 30 minutes, depending on the size of the compacts.

The the rmal cycling results will be discussed with reference to the methods of fabrication outlined above. Tables III and IV contain summaries of the experimentally measured dimensional changes of all the cycled compacts, along with qualitative observations regarding surface quality and characteristics such as roughening, seams, cracks, etc. 
III. RESULTS

1. Cold Compacted and Sintered Specimens (Nos, U-34A, B, C and E) *

These specimens were cut from a rectangular piece that had been cold compacted and sintered at $1125^{\circ} \mathrm{C}$. The "as-sintered" dimensions were: 0.365 in. wide by 0.450 in. thick by 10.5 in. long, whth the thickness dimension representing the direction of pressing on compacting. The cycling specimens were cut so that their length, width, and thickness directions were parallel to the corresponding directions in the "as-sintered" piece. The cycling specimens were finished to the dimension shown in Table IIl by grinding. Upon Woosher cycling for 200 times, all except U-34E grew in all directions, with the largest growth occurring generally in the thickness dimension (pressing direction). Specimen U-34F shrank in length and grew in width and thickness. After 150 cycles, the maximum values of growth and shrinkage in any direction were $12.4 \%$ and $-0.26 \%$ respectively. The recorded dimensional changes are subject to considerable error because of surface roughening which, as shown in Figure 1, was quite pronounced after only 100 cycles. After 200 cycles, the specimens were roughened and distorted to a degree that precluded even an approximate measurement of the dimensional changes. From past observations the pronounced roughening may be attributed to the coarse grain size established at the high sintering temperature, as illustrated in Figure 2 .

After 200 cycles the specimens were reground and their bulk densities determined from their weights and volumes (the latter measured by micrometer). The densities decreased slightly from an initial value of $17.2 \mathrm{gms} / \mathrm{cc}$ to values ranging from 17.1 to $16.7 \mathrm{gms} / \mathrm{cc}$. This decrease may be attributed to the initial porous nature of the compacts (see Figure 3), and the severe cracking that occurred during cycling (see Figure 1).

\section{Cold Compacted, Sintered, Repressed and Annealed Specimens}

Cycling specimens No. $76 \mathrm{~B}-1$ and 2 were cur from a cold compacted. and sintered specimen that had been repressed at room temperature and annealed for 1 hour at $500^{\circ} \mathrm{C}$. The cycling specimens were finished to size by surface grinding. The thickness dimension represented the repressing direction. Upon Woosher cycling both specimens grew more or less uniformly in all directions. The maximum growth observed in any direction after 500 cycles was $5.88 \%$. Roughening was slight but the specimens developed deep surface cracks (see Figure 4). A qualitative indication of the extent of the cracking is provided by the fact that the specimens exuded NaIK for some time after testing. The porosity in this material, illustrated in Figure 5, was somewhat more prominent than in the $U-34$ specimens. The microstructure could not be satisfactorily resolved but the grain structure

*Identification numbers of specimens are those supplied by Sylvania.

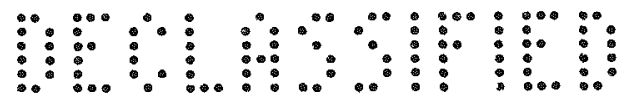




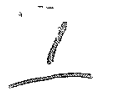

appeared large and irregular. Sub-graining has been noted by Sylvania on similarly treated material. (2) The difficulty of revealing the microstructure metallographically arose from the fact that the voids enlarged during electropolishing to the point of scattexing the incident light beam so much that the image was blotted out. Best results, although not very satisfactory, were obtained by electropolishing directly after lead lapping on $900 \mathrm{grit}$ abrasive. This procedure tended to fill the voids, thus avoiding excessive preferential dissolution around them. This technique revealed grain outlines in large-grained specimens, but was inadequate for fine-grained specimens.

Densities were obtained after cycling in a manner similar to that used for the U-34 specimens. The densities decreased from initial values of 16.4 and $16.2 \mathrm{gms} / \mathrm{cc}$ to 13.6 and $14.1 \mathrm{gms} / \mathrm{cc}$. Porosity and cracking are probably the cause of this decrease, with the tendency of the NaK to expand the pores during cycling, a possible contributing factor.

Specimens No. $168-1$ and 2 were cut in the form of small cubes from a rectangular sintered compact about $6 \mathrm{in}$. long by $0.8 \mathrm{in}$. thick by $0.5 \mathrm{in}$. wide. The cubes were first repressed in the same direction as the original compact (thickness direction) and then repressed again on the other faces (rotations of $90^{\circ}$ ). The specimens were then annealed for one hour at $1090^{\circ} \mathrm{C}$ and machined to approximately $0.5 \mathrm{in}$. on each side. In 200 Woosher cycles, growth varied from $3.71 \%$ to $8.38 \%$ in width, $3.04 \%$ to $4.30 \%$ in thickness, and $1.54 \%$ to $2.38 \%$ in length. $\%$ It is apparent that in some directions growth occur red at rates notably higher than in the $76 \mathrm{~B}$ series above. The above growth rates are to be considered as approximate because of errors of measurement due to surface roughening (see Figure 6). Densities, initially 18.03 and $18.1 \mathrm{gms} / \mathrm{cc}$, remained essentially unchanged; as determined by the carbon tetrachloride immersion method. The specimens did not show any indications of cracking.

3. Hot Pressed Specimens Made from Uranium Powders

Cycling specimens No. 509-1 and 510-1 were cut and ground from discs, $1.44 \mathrm{in}$. in diameter by approximately $0.3 \mathrm{in}$. thick, that had been made by hot pressing at $600^{\circ} \mathrm{C}$, with the pressure applied in the thickness direction. The thickness direction in the cycling specimens corresponded to the direction of pressing; the length and width directions were arbitrary radial directions with reference to the "as pressed" discs. The specimens were of uniform fine grain size (average diameter $0.025 \mathrm{~mm}$ or less) and the densities were considerably higher $(18.77$ and $18.78 \mathrm{gms} / \mathrm{cc})$ than those of any of the sintered specimens described above.

*These are arbitrarily assigned directions and may not be related to corresponding directions in "as pressed" specimens.

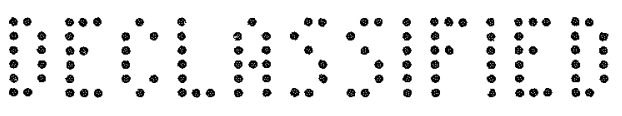


Upon Woosher cycling both specimens shrank in thickness (pressing direction) and grew in width and length (radial directions of disc) Maximum shrinkage after 500 cycles was $2.6 \%$ maximum growth $1.6 \%$. Both pieces were very slightly roughened and warped as shown in Figure 7. All edges were slightly raised producing a "wire edge" effect. No evidence of cracking or porosity was seen in either specimen after cycling. Density measurements after cycling (by carbon tetrachloride immersion method) showed no significant decrease.

In an attempt to remove orientation effects, the specimens were reground, beta treated ( 4 minutes at $725^{\circ} \mathrm{C}$ - water quenched) and recycled another 500 times. Dimensional changes were inconsistent between the two specimens. No. 509-1a grew in all directions with the greatest growth (1.5\%) occurring in the thickness direction, while No. $510-1 \mathrm{~b}$ shrank in width and thickness ( $1.1 \%$ and $0.6 \%$ respectively) and grew in length $(0.9 \%$ ). In consequence of the coarsened grain structure resulting from the beta treatment, (compare Figures 8 and 9) the surface roughening was considerably more pronounced (compare Figure 10 with Figure 7).

For comparison with these compacts, two rolled and beta treated uranium rods, 1 in. long $x 3 / 8$ in. in diameter, were similarly cycled. After 500 cycles the growths ranged from $1.27 \%$ to $1.40 \%$ in length and from $0.2 \%$ to $0.47 \%$ in diameter, the latter values being subject to considerable experimental error due to surface roughening (see Figure 11). From the results it may be inferred that the order of magnitude of the dimensional changes was the same for both the powder compacts and the rolled and beta treated specimens. Roughening, as might be expected, was more pronounced after beta treatment.

Cycling specimens No.611-1 through 7 were cut from a 1.4 in. diameter $x 4$ in. long rod which had been hot pressed from uranium powder in a single pressing operation, with the pressing direction parallel to the cylindrical axis of the rod. The rectangular cycling specimens were sectioned so that the pressing direction was represented by the thickness dimension in specimens 1,4 , and 7 , and by the length dimension in specimens $2,3,5$ and 6. Their grain structures were uniformly fine (about 20 microns) and their densities ranged from 18.56 to $18.72 \mathrm{gms} / \mathrm{cc}$. Their thermal cycling stability was similar in all respects to that of the hot pressed compacts described previously: shrinkage occurted in the pressing direction and growth in directions normal to the pressing direction. Maximum shrinkage in 500 cycles was $1.5 \%$, maximum growth $3.4 \%$; roughening and warp were very slight (see Figure 12).

Specimen Nos.671,673 and those of the 1300 series (see Tables I and III) were hot pressed in a single operation at $600^{\circ} \mathrm{C}$, into slugs $1.3 \mathrm{in}$. in diameter by 2 and $4 \mathrm{in}$. long and were cycled in full size. The average grain diameters of Nos. 671 and 673, ascertained from a hardness relationship, (2) were of the order of $0.02 \mathrm{~mm}$ or less. The six slugs in the 1300 
scries were of slightly finer grain size with average diameters of the order

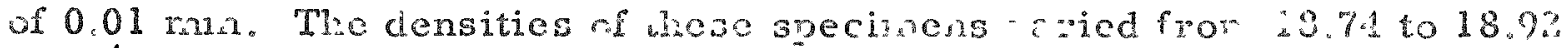
grms/cc. Upon induction cycling, all slugs shrank in length (pressing direction) and grew in diameter. Shrinkage in 250 cycles ranged from $0.52 \%$ to $0.81 \%$ in Nos. 671 and 673 and from $0.17 \%$ to $0.52 \%$ in all compacts of the 1300 series. Representative compacts of the 1300 series shrank upon further cycling (700 times) from $0.88 \%$ to $1.19 \%$. The centerless ground compacts of this series shrank slightly less than those cycled "as pressed and electropolished."

Compact No. 673 was the only one in this group that showed any notable evidence of surface roughening (see Figure 13). Compacts 671 and 673 showed slight to pronounced "wire edge" effects. This "wire edge"effect was observed on only one end of the compacts, usually the upright end on vertical cycling. Compacts of the 1300 series had only slight "wire edge" effects (Figure 14), except No. 1392 which showed a pronounced "wire edge" effect as well as definite circumferential cracks or crevices. The only other significant physical defect was a vee-shaped crack, about $3 / 8$ in. deep, observed on the circumference of slug No. 1361. In all the 4 in. slugs (1300 series) the die parting line was evident after 250 cycles; after 700 cycles a slight ridge at the parting line was noted.

Specimens No. 645 and 651 were hot pressed and repressed to a final size of $1.2 \mathrm{in}$. in diameter by $4.0 \mathrm{in}$. long. Similarly cycled, both compacts shrank in length (pressing direction) and grew in diameter. After 250 cycles, shrinkages in length ranged from $0.39 \%$ to $1.32 \%$, which is of the same order of magnitude as that obtained on the 2 in. compacts discussed above (Nos. 671 and 673). Roughening of No.651 was slight to moderate: in No. 645 it was quite pronounced, as shown in Figure 15. Circumferential crevices were noted at regular intervals along the length of both compacts.

\section{Hot Pressed Specimens Made from Uranium Hydride Powders}

Specimens No, 625-1 and 2 and $634-1$ and 2 were sectioned from hot pressed discs approximately $1-3 / 8 \mathrm{in}$. in diameter 0.3 in. thick. The press ing direction in the sectioned cycling specimens was represented by either the width or thickness dimensions. Growth after 500 cycles on $625-1$ and 2 was greatest in the thickness direction (maximum $2.4 \%$ ), due in most part to surface roughening, shrinkage occurred in the width of both specimens $(0.29 \%)$ and in the length of specimen No.625-1 $(0.58 \%)$. Surface roughening on the thickness surfaces was quite pronounced; the other surfaces remained relatively smooth, as shown in Figure 16a. Sharp edges were present on both samples after 200 cycles.

Compacts No. 634-1 and 2 were cut from a similarly hot pressed disc, using sufficient coolant in cutting to prevent overheating, since it was thought that the roughening on the thickness surfaces of the previous specimens

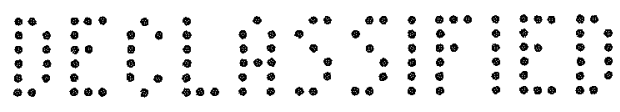


might have arisen from such circumstances. Upon similar cycling, very little surface roughening was evident after 500 cycles, as shown in Figure $16 \mathrm{~b}$. Both specimens shrank in length (maximum 1.8\%) and grew in width (maximum 1.2\%) and thickness (maximum 3.4\%). These dimensional changes are probably more nearly representative of this material, since improper sectioning was avoided.

Specimens No. $674,25,26,31,35,36$ and 48 were cylindrical slugs, 1.3 in. in diameter by 2 or 4 in. long, hot pressed in a single operation at $600^{\circ} \mathrm{C}$ at a pressure of $11 \mathrm{tsi}$. Except for starting material (UH 3 powder) fabrication details were the same as for the compacts in the 671-673 and 1300 series discussed above. Average grain diameters were $0.01 \mathrm{~mm}$ or less and densities ranged from 18.84 to $18.92 \mathrm{gms} / \mathrm{cc}$. With the exception of No.674, all compacts shrank in length (pressing direction) and grew in diameter upon induction cycling. After 250 cycles the maximum shrinkage was $0.85 \%$ and maximum growth $0.63 \%$. After 700 cycles, representative compacts had shrunk $1.67 \%$ and grown $1.24 \%$ (maximum values in both cases). The range of values for all compacts (with exception of No. 674) were of about the same order of magnitude regardless of whether surfaces had been electropolished or centerless ground prior to cycling. No. 674 grew in length $(0.88 \%)$ and became elliptical in cross section after 250 induction cycles. No evidences of roughening or "wire edge" effects were noted in any of the above compacts after cycling (see Figures 13 and 14); however, die parting lines were evident on all the 4 in. compacts.

Specimens No. 680 and 696 were made by sinterwelding initially hot pressed components, approximately $2 \mathrm{in.}$ long by $1.3 \mathrm{in}$. in diameter, into 4 and $8 \mathrm{in}$. slugs xespectively. A charge of approximately $25 \mathrm{grams} \mathrm{UH}_{3}$ powder was placed between the components and hot pressed at $600^{\circ} \mathrm{C}$ in the usual manner. Slug No. 696 was machined and centerless ground to $3 / 4$ in. in diameter for cycling. Average grain diametexs in both compacts were $0.025 \mathrm{~mm}$ or less, with densities ranging from 18.90 to $18.92 \mathrm{gms} / \mathrm{cc}$. Upon induction cycling, No. 680 grew only $0.5 \%$ in 250 cycles. Changes in diameter were exratic in that one of the original $2 \mathrm{in.}$ components shrank a maximum of $0.54 \%$, while the other grew a maximum of $0.41 \%$. Pronounced wire edges were evident on the upright end as shown in Figure 17, but only very slight surface roughening was noted. The sinterweld area and the die parting line were visible after cycling. Scattered longitudinal hairline cracks were noted.

The 8 in. compact, No 696, was induction cycled 700 times. For comparison, a beta treated uranium rod (No. 108) * of equivalent length and diameter was cycled along with the compact. The sinterwelded compact grew $0.40 \%$ in length and $0.66 \%$ in diameter, while the beta treated rod grew

*Rod No. 108 was rolled $38 \%$ at $300^{\circ} \mathrm{C}$, beta treated for 8 minutes at $725^{\circ} \mathrm{C}$, water quenched and centerless ground. 
$1-$

$3.28 \%$ in length and shrank $0.67 \%$ in diameter. The surface appearance of both rods after cycling is shown in Figure 18. The compact had no "wire edges" and the surface was considerably less roughened than that of the beta treated rod; however, there was considerable out-of-roundness, giving the compact a wavy, irregular surface along its length. The diameters of the compact at the weld areas were about $0.004 \mathrm{in}$. smaller than at other locations.

5. Effects of Cycling Variables

To evaluate the effects of cycling variables, two specimens, $3 / 8 \mathrm{in}$. in diameter by 1 in. long, were machined from the centers of compact Nos. 25 and 1354 and Woosher cycled under two different conditions. A transfer time of 5 seconds heating and cooling was used on two specimens, while a 15 minute heating - 5 second cooling transfer time was used on the other two specimens. Cycling occurred between $50^{\circ} \mathrm{C}$ and $550^{\circ} \mathrm{C}$ with holding times of 2 minutes in the cold tank and 5 minutes in the hot tank. The results after 200 cycles are presented below.

\begin{tabular}{|c|c|c|c|}
\hline \multirow[b]{2}{*}{ Cycling Conditions } & \multirow[b]{2}{*}{$\begin{array}{c}\text { Number of } \\
\text { Cycles }\end{array}$} & \multicolumn{2}{|c|}{ Percent Change in Length } \\
\hline & & $\begin{array}{c}\mathrm{A}-25 \\
\left(\mathrm{UH}_{3} \text { Powder }\right)\end{array}$ & $\begin{array}{c}\text { A-1354 } \\
\text { (U Powder) }\end{array}$ \\
\hline $\begin{array}{l}5 \text { seconds heating } \\
\text { and cooling trans- } \\
\text { fer times }\end{array}$ & 200 & -0.57 & -1.16 \\
\hline $\begin{array}{l}15 \text { minute heating - } \\
5 \text { second cooling } \\
\text { transfer times. } \\
\text { ("Slow heating- } \\
\text { fast cooling" } \\
\text { cycle) }\end{array}$ & 200 & +0.15 & +0.91 \\
\hline
\end{tabular}

Using the "equal heating and cooling rate" cycle, specimen No. 1354 had a higher shrinkage rate than No. 25. The "slow heating-fast cooling" cycle caused both specimens to grow, with No. 1354 having the greater rate. This influence of cycling variables upon the direction of dimensional changes is consistent with that observed in alpha rolled as well as beta treated uranium. (5) A "slow heating-fast cooling" cycle increases the growth in either case. 


\section{DISCUSSION OF RESULTS}

Uranium powder compacts fabricated by cold compacting and sintering in the gamma range were of low density, approximately $17 \mathrm{gms} / \mathrm{cc}$, and of extremely large and irregular grain size. Thermal cycling produced large, and non-uniform dimensional changes, excessive cracking, and pronounced surface roughening.

Cold compacted, sintered, repressed and gamma annealed compacts were also characterized by a large and irregular grain size. The final density varied widely depending upon pressures, temperatures and repressing operations; however, at best it was considerably below theoretical values. Dimensional changes and surface roughening upon thermal cycling were moderate to severe, depending upon the grain size and density. Cold repressing followed by alpha annealing, as contrasted to gamma annealing, produced a somewhat more stable compact. No correlation between pressing directions and the directions of the dimensional changes upon thermal cycling could be found for the materials that had been heated into the gamma temperature range prior to cycling. The pronounced surface roughening made accurate measurements of the dimensional changes difficult, and the reported values should be interpreted as approximations only.

Hot pressing of uranium or uranium hydride powders in the high alpha temperature range produced compacts of higher densities and uniformly smaller grain sizes. Hot pressed specimens made from uranium powders invariably shrank in the direction of pressure application. No such correlation could be found in the hot pressed specimens made from uranium hydride powders. Upon Woosher cycling, the dimensional changes of hot pressed compacts, made from either uranium or uranium hydride powders, were of about the same order of magnitude as those obtained in beta-treated rolled uranium, except for considerably diminished surface roughening effects. In this connection, it should be emphasized that a beta treatment of the hot pressed compacts reduced the dimensional changes only slightly but increased the surface roughening noticeably, presumably because of increased grain size.

The magnitude of dimensional changes of hot pressed compacts upon induction cycling was lower in all cases than upon Woosher cycling. This is a characteristic of the two cycling units that is directly related to the cycling variables, chiefly heating and cooling rates. $(4,5)$ The surface roughening of full-sized rods pressed in a single operation was negligible, but other defects were occasionally noted, such as metal overlapping, cir cumferential cracks or crevices, wire edges, and die parting marks. "Wire edge" effects were less evident in the compacts made from uranium hydride and were further minimized by finishing to size by surface grinding.

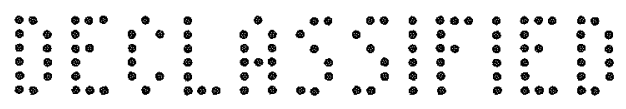




$$
15
$$

The two compacts that were produced by pressing and repressing in a graphite sleeve were less stable in all respects. Shxinkage was high $(1.32 \%$ in only 250 cycles), roughening was pronounced, and surface defects were present. Based on surface appearance alone, one would hesitate to recommend this fabrication technique of pressing and repressing as a means of producing suitable 4 in. compacts, although it should be borne in mind that only two such compacts were examined.

The two "sinterwelded" compacts grew only $0.66 \%$ maximum after 700 induction cycles. Surface roughening was very slight, but slight "wire edges," out-of-roundness, and surface cracks were present. It should be noted that even though the individual components, from which the 8 in. long rod was made, shrank in length and grew in diameter, the composite tended to grow in all directions. The weld areas were visible after cycling in all cases.

The dimensional changes of the 8 in. long sinterwelded compact were lower in magnitude than those of a beta-treated rolled uranium rod of similar dimensions and cycled under identical conditions $(0.40 \%$ vs. $3.28 \%$ growth $)$. From past observations on numerous other beta-treated rolled rods, however, the noted growth of this particular beta-treated rod appears abnormally high, and a comparison of the relative growth stability of the two types of products based on only a single set of measurements cannot be made without considerable reservations. No such qualifications exist, however, in regard to surface roughening; the problem is practically eliminated in suitably fabricated compacts.

In general, the cycling results indicate that even in the hot pressed compacts there is retained a minor orientation effect, arising from the directionality of the pressing operation, which makes itself felt in a preferential directional growth or shrinkage on thermal cycling. The influence of this orientation effect upon the dimensional changes may be altered by cycling variables in a manner consistent with that observed on alpha rolled as well as beta treated uranium. 


\section{CONCLUSIONS}

The data in this report indicate that compacts of nearly theoretical density and fine grain size can be obtained by hot pressing uranium or uranium hydride powders in the high alpha temperature range. Large diameter compacts ( $1.4 \mathrm{in}$. in diameter) of varying length are best made by hot press ing in a single operation or by sinterwelding of individual hot pressed components. The magnitudes of growth or shrinkage of such compacts upon thermal cycling approximate those of beta-treated rolled uranium; the surface wrinkling problem, however, associated with beta treatment is practically eliminated in the alpha pressed powder compacts.

\section{BIBLIOGRAPHY}

1. L. R. Kelman, Dimensional Changes in Uranium Under Thermal Cycling, Journal of Metallurgy and Ceramics, TID-68, Is sue No. 4, Sept. 1949, pp. 7-40.

2. J. L. Zambrow, H. H. Hausner, The Control of Grain Size in Sintered Uranium Compacts, SEP-72, Aug, 30, 1951

3. H. H. Hausner, N. P. Pinto, The Production of Uranium Powder, SEP-16, May 26, 1949.

4. R. M. Mayfield, S. T. Zegler, Thermal Cycling Equipment, ANL-4848, Nov. 1, 1951.

5. R. M. Mayfield, The Effect of Cycling Variables Upon the Growth Rate of $300^{\circ} \mathrm{C}$ Rolled Uranium, ANL-4905, June 1, 1952 . 
Figure 1.

Surface appearance of Compacts U- 34 A, B, C and E after wroosher" Cycling between $50^{\circ} \mathrm{C}$ and $600^{\circ} \mathrm{C}$.

(Cold Compacted and Sintered)
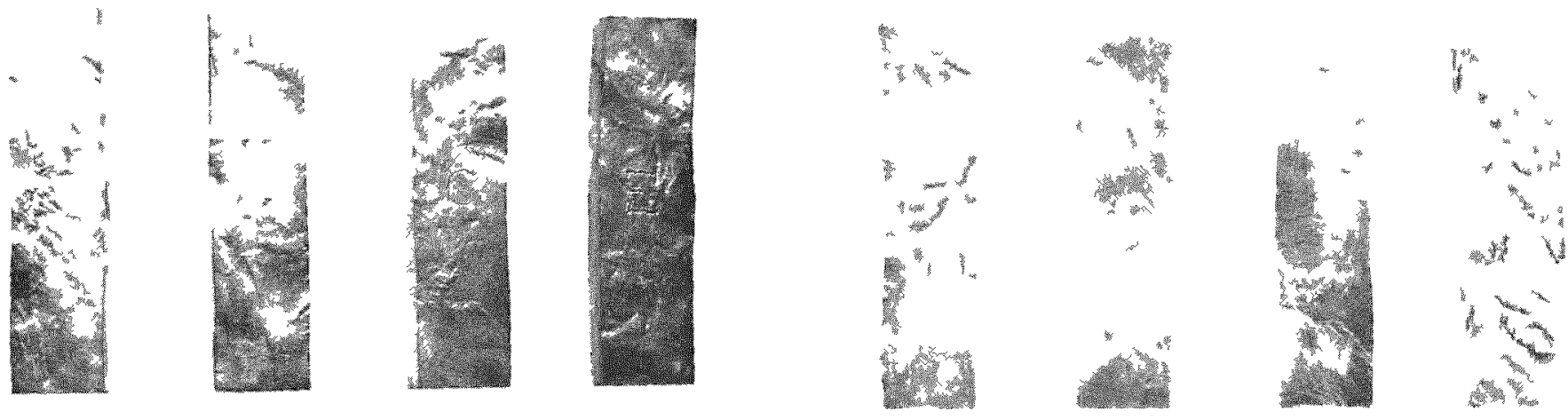

U34

A

Macro 4561

B

C

E A after 100 cycles approx. 2x Macro 44596

B

C

E after 200 cycles

\section{Figure 2.}

Microstructure of Specimen U-34C before cycling.

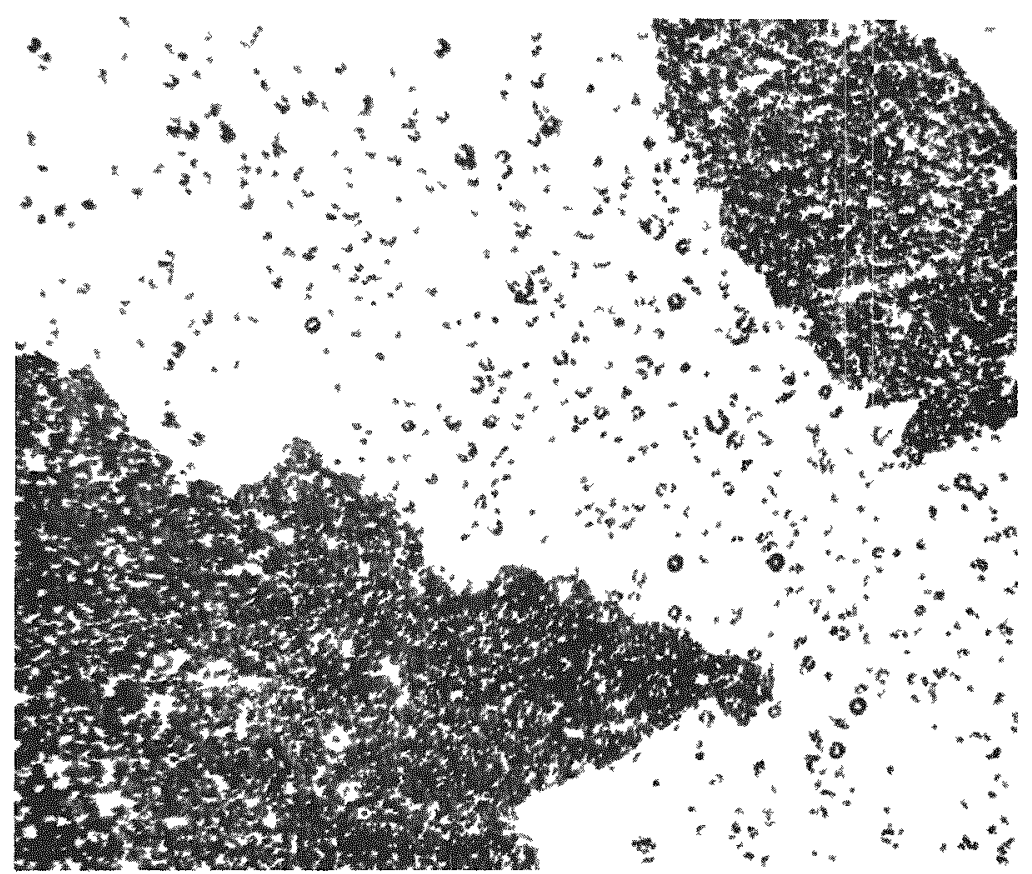

$$
\begin{gathered}
\text { Micro \#6987 } \mathrm{H}_{3} \mathrm{PO}_{4} \text { Electrolytic Polish } 50 x \\
\text { Polarized light }
\end{gathered}
$$


Figure 3.

Porosity in Specimen $\mathrm{U}-3 \mathrm{~L}_{\mathrm{C}} \mathrm{C}$ before cycling.

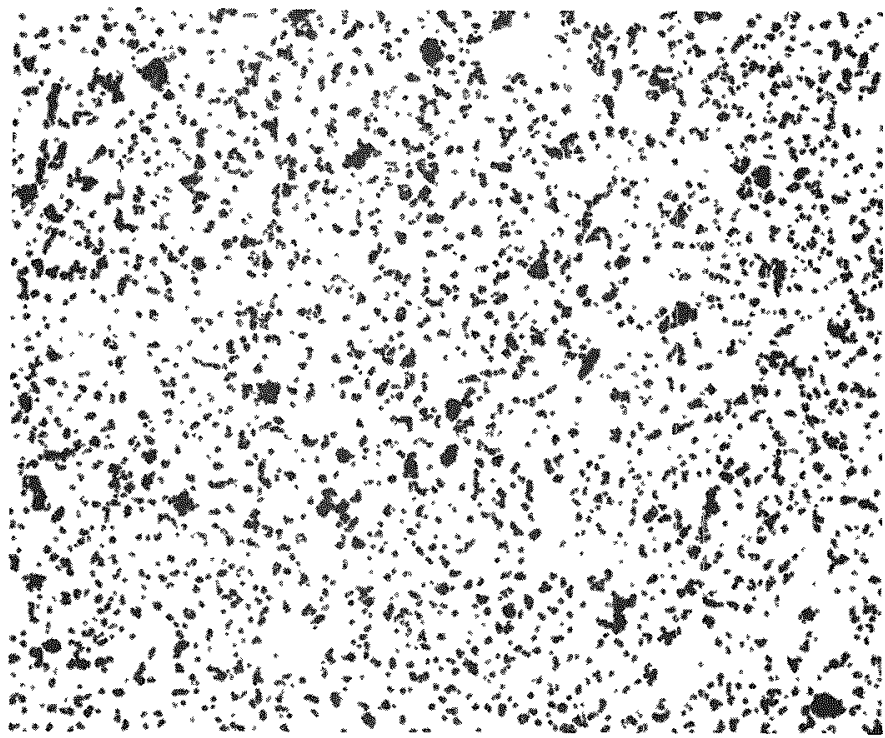

Micro \#6986 Mechanical Polish 200x Bright Field.

Figure 4 .

Surface Appearance of Compacts $76 B-1$ and 2 after 500 Woosher Cycles.

(Cold Compacted, Sintered, Repressed and Annealed)

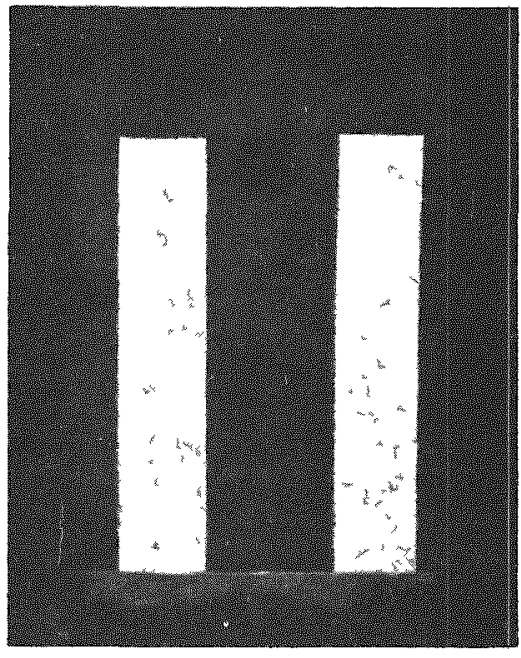

$76 B=1$

$76 \mathrm{~B}=02$

Macro 44640 approx. Ix 
Figure 5 .

Porosity of Specimen $76 \mathrm{~B}-2$ before cycling. (Cold Compacted, Sintered. Repressed and Mlpha Annealed)

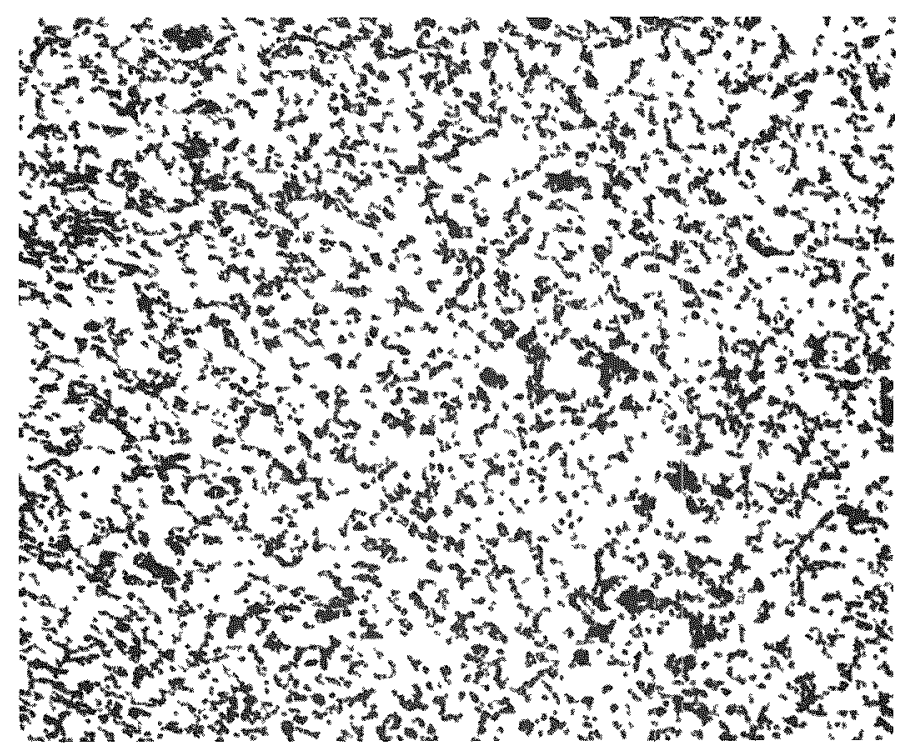

Micro \#6982 Mechanical Polish $100 x$ Bright Field.

Figure 6.

Surface Appearance of Compacts 168-1 and 2 after 200 Woosher Cycles.

(Cold Compacted, Sintered, Repressed and Gamma Annealed)
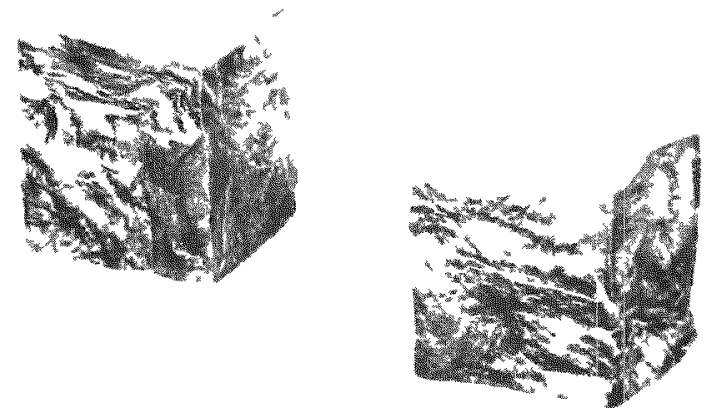

Macro 7904

approx. $2 x$ 
Figure 7.

Surface Appearance of Hot Pressed Compacts 509-1 and 510-1 aiter 500 Woosher Cycles.

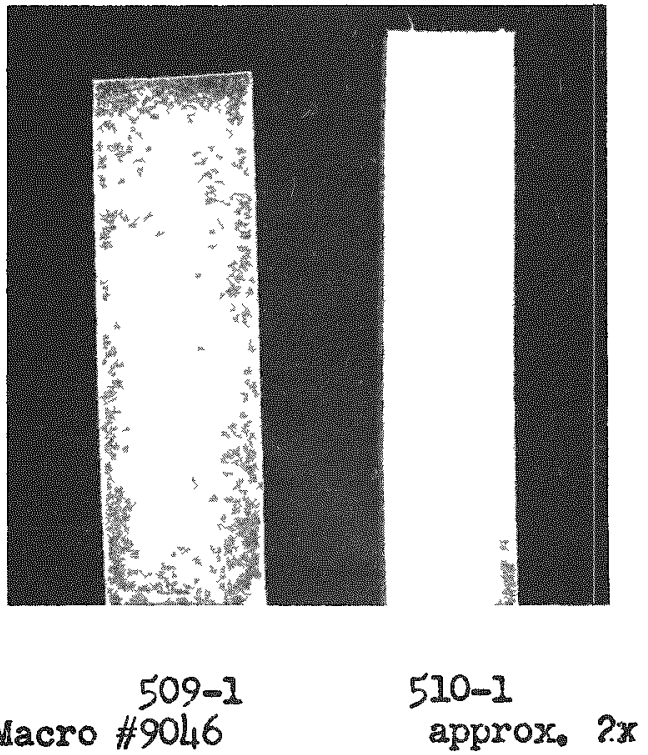

Figure 8.

Microstructure of Hot Pressed Compact 510-1 after 500 Woosher Cycles.

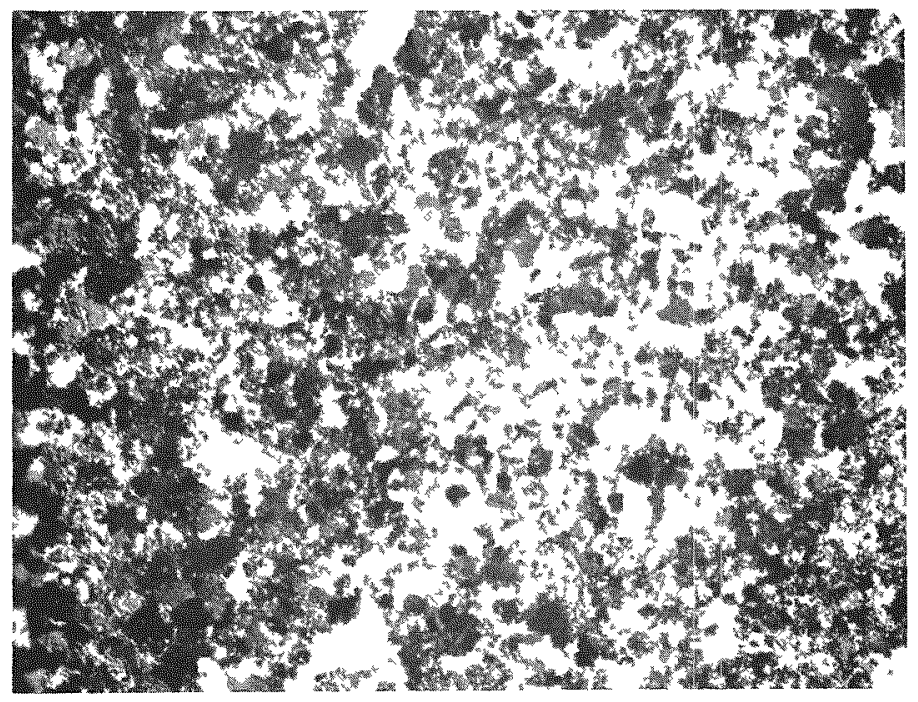

\footnotetext{
Micro $\# 10,197 \mathrm{H}_{3} \mathrm{PO}_{4}$ Electrolytic $250 \mathrm{x}$ Pollsh Polarized Light.
} 
Figure 9.

Microstructure of Beta Treated Hot Pressed Compact 509-1 after 500 Woosher Cycles. (Compact previously cycled 500 times in asreceived condition)

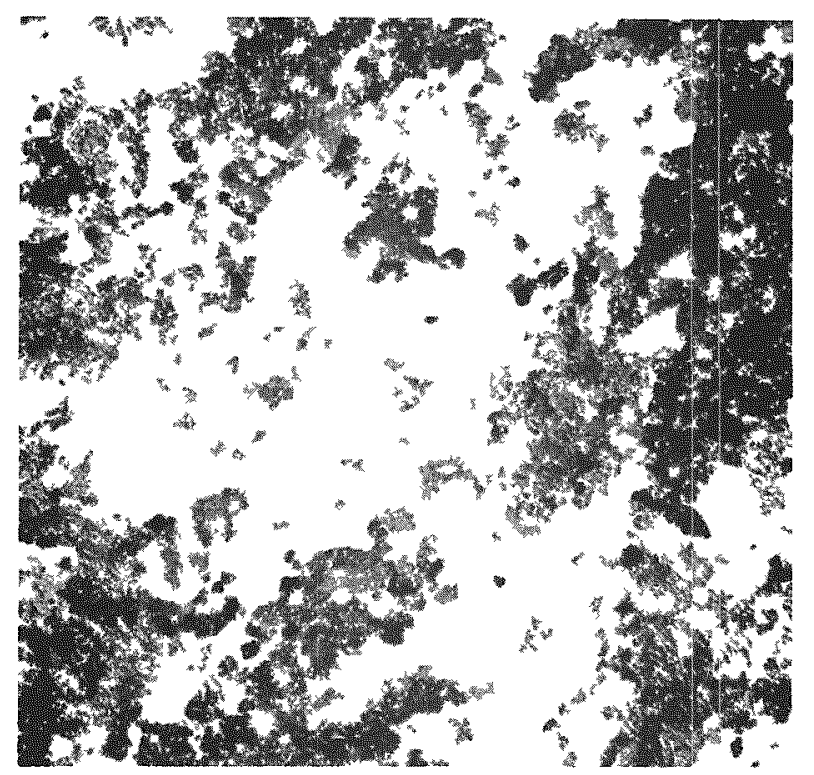
Micro $10,199 \quad \mathrm{H}_{3} \mathrm{PO}_{4}$ Electrolytic $250 \mathrm{x}$ Polish, Polarized Iight.

Figure 10.

Surface Appearance of Beta Treated Hot Pressed Compacts after 500 Woosher Cycles.

(Compacts previously cycled 500 times in as-received condition)
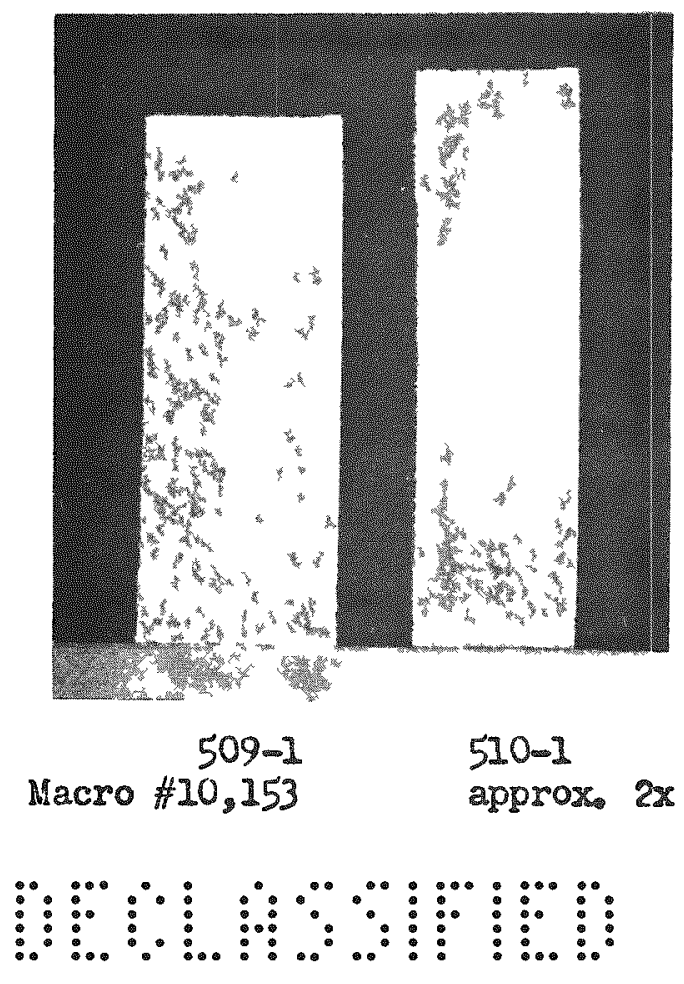
Figure 11.

Surface Appearance of Rolled and Beta Treated Rods after 500 Woosher Cycles.
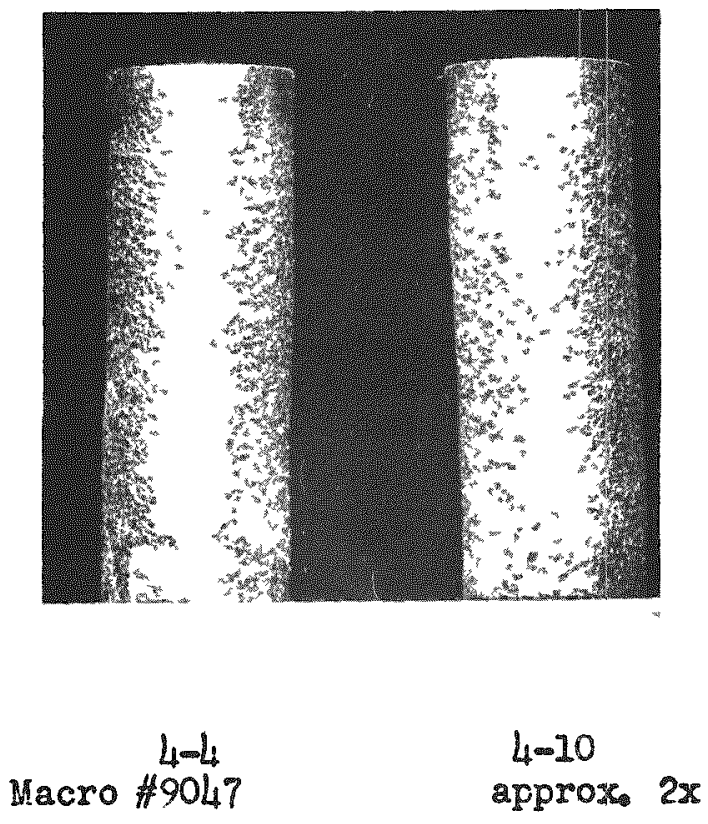

Figure 12.

Surface Appearance of Hot Pressed Compacts 611-1 through 7 after 500 Woosher Cycles.

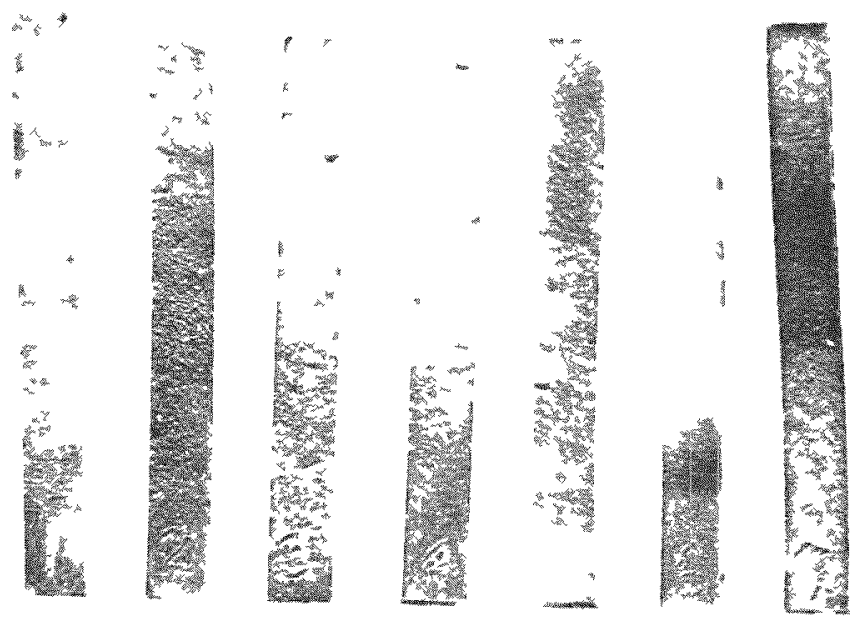

Macro $\# 11,024$

approx. $2 x$ 


\section{3}

Figure 13.

Surface and End Appearances of Compacts Nos, 67,673 and 674 after 250 Induction Cycles Between $100^{\circ} \mathrm{C}$ and $55^{\circ} \mathrm{C}$. (Pressed in single operation)

a. End appearances.

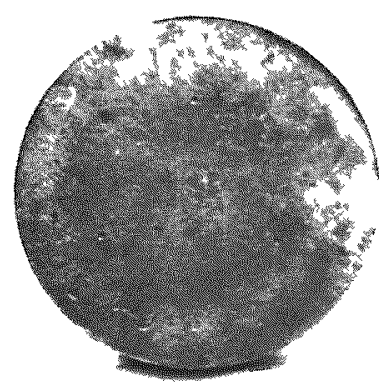

No, 671, U-Ponder Macro 11,764

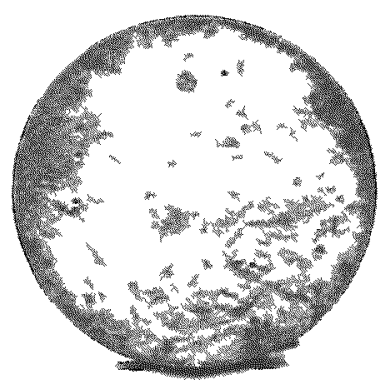

No. 673, UnPowder

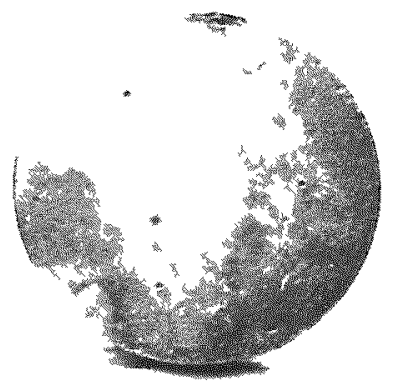

No. 674, $\mathrm{UH}_{3}$ Powder

b. Surface appearances.
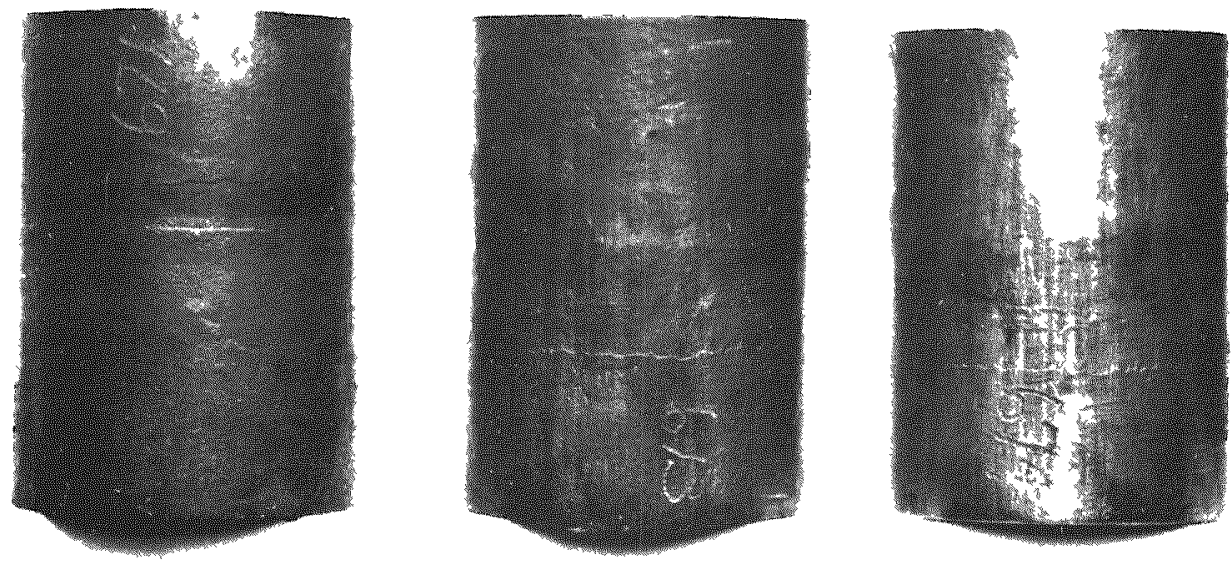

No. 671, V-Powder Macro \#11,763

No. 673, U-Powder No. 674, UH, Powder 
Figure 14.

Surface Appearance of Compacts Nos. 1359, 1392, 26 and 48 After 700 Induction Cycles.

$$
\text { (Pressed in Single Operation) }
$$
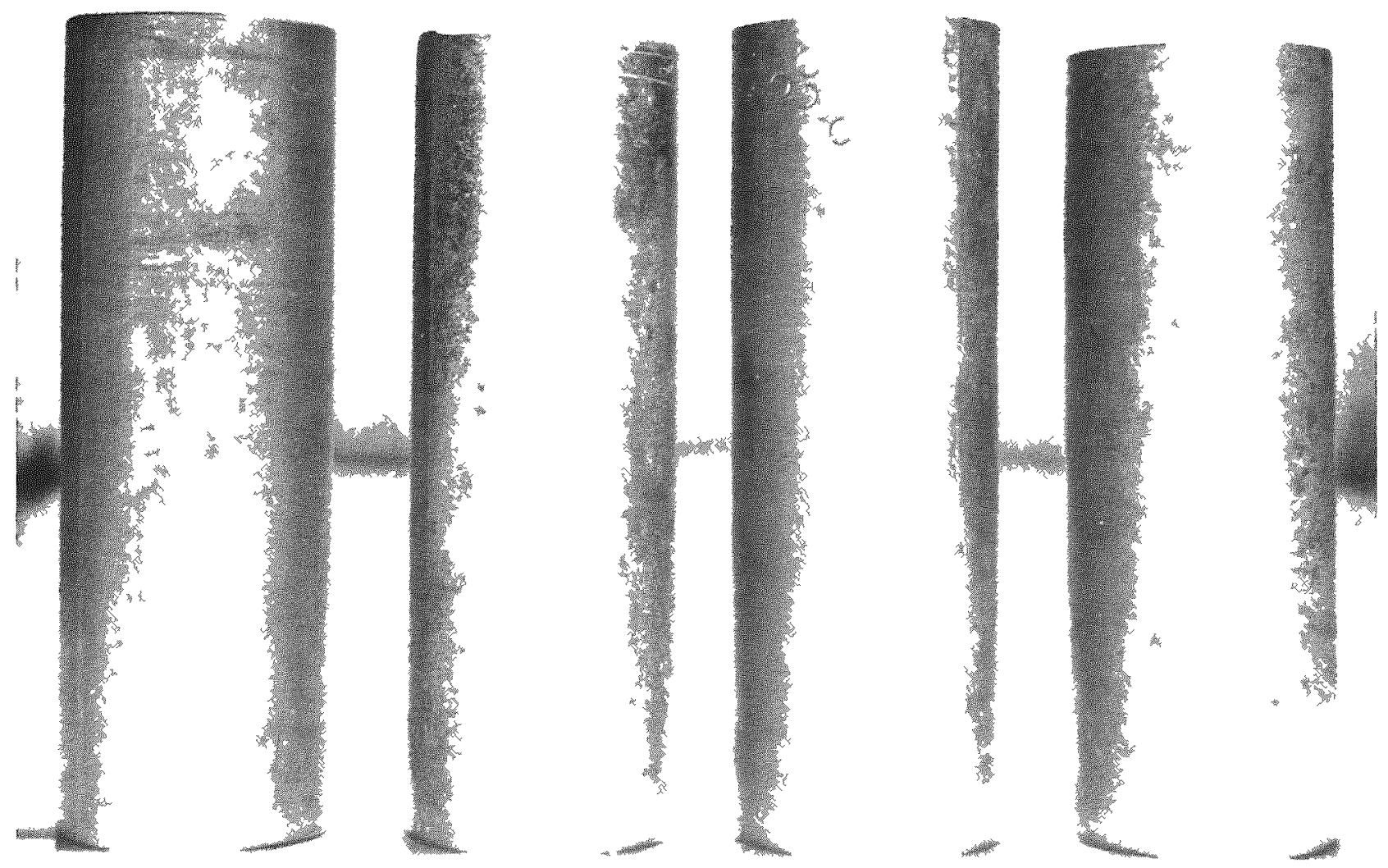

Macro 13.596

1359

1392

26

$48^{\operatorname{approx} \cdot 2 x}$

Raw Material: U

Surface:

As Pressed

and Electropolished
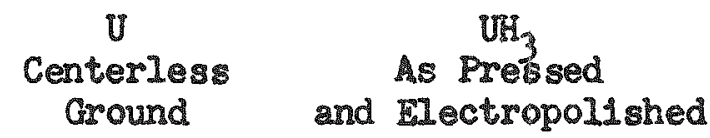

$\mathrm{UH}_{3}$
Centerless
Ground 
Figure 15.

Surface Appearance of Compacts Nos, 645 and 651 After 250 Induction Cycles.

(Fabricated by Pressing and Repressing Techniques)

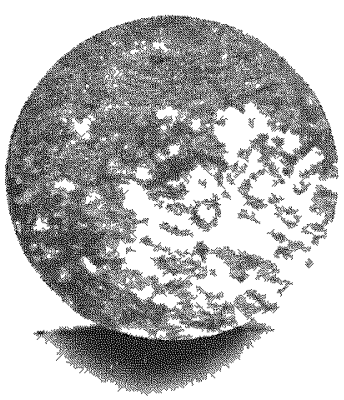

Macro \#11,766 No. 645

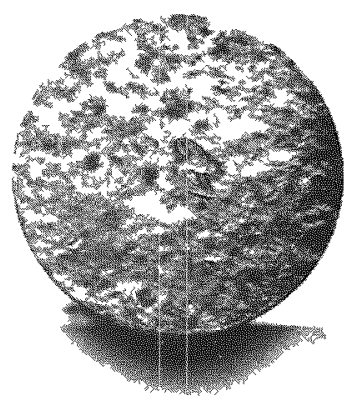

2pprox. $1 x$ No. 651
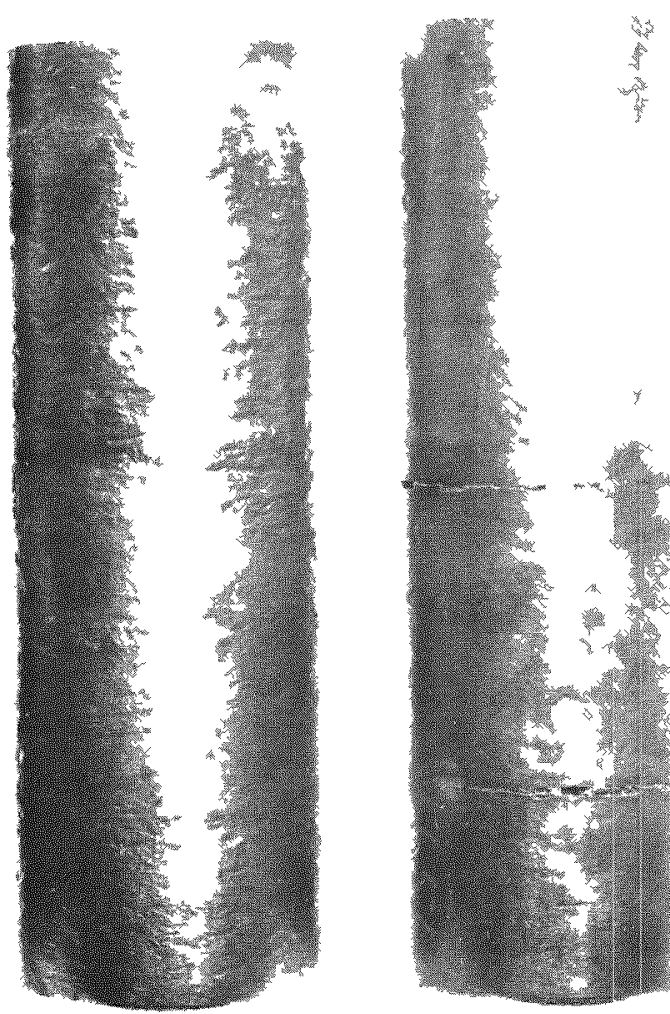

Macro \#11,765

Raw Material: U-Powder

approx. $1 x$

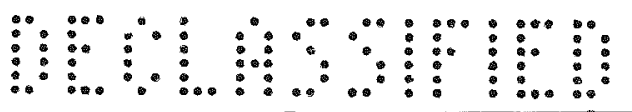


Figure 16.

Surface Appearance of Hot Pressed Compacts Nos. 625 and 634 After 500 Woosher Cycles.
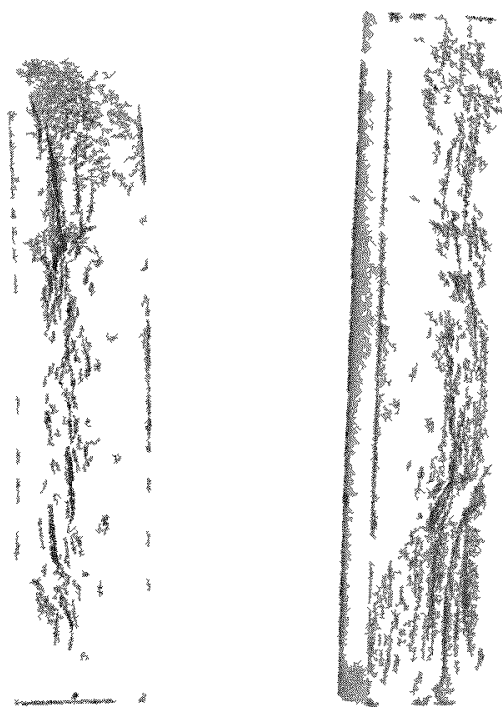

$625-1$
Macro $\# 11,309$

$625-2$

approx. $2 x$

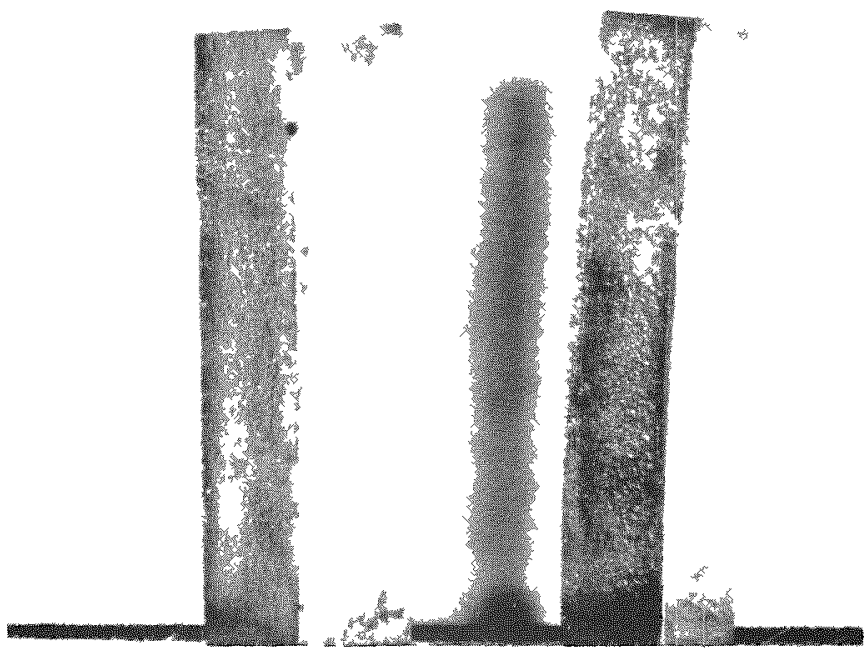

Nacro $13,431 \quad 634-2$ approx. $2 x$

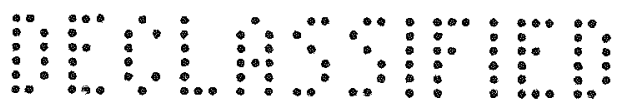


Figure 17.

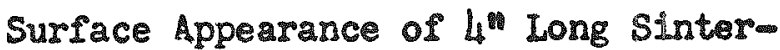
welded Compact No. 680 after 250 In duction Cycles.

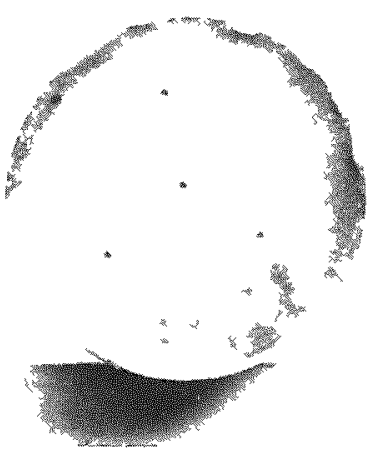

Macro \#17,766 approx $2 x$

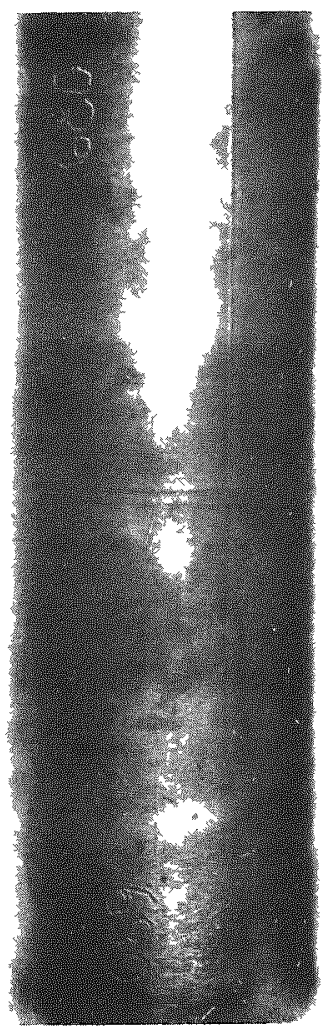

Macro \#11,765 approx, $1 x$

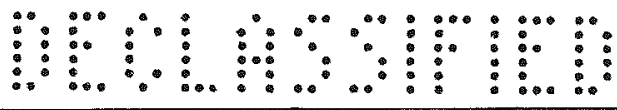


Figure 18.

Surface Appearance of Beta Treated Rolled Uranium Rod and Sinteswelded Compact No. 696 After 700 Induction Cycles.
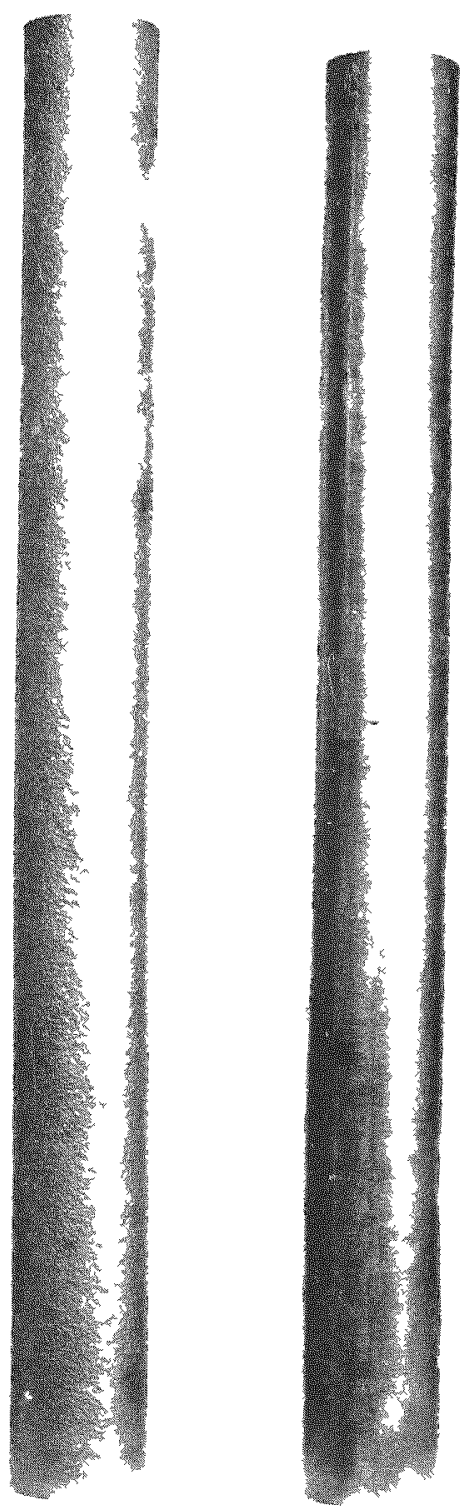

Macro \#11,977 Beta Troated Rod 108

$3 / 4 x$ Compact 696

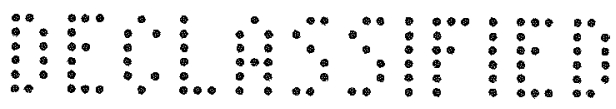


Table I

FABR ICATION DATA OF SPECIMENS MADE FRON URANILM POWDEHS ${ }^{(4)}$

\begin{tabular}{|c|c|c|c|c|c|c|c|c|c|c|c|}
\hline \multirow{2}{*}{$\begin{array}{l}\text { Specumen } \\
\text { NNo. }\end{array}$} & \multirow{2}{*}{$\begin{array}{l}\text { Raw Matera } a 1 s \text { and } \\
\text { Fabrication Methods }\end{array}$} & \multicolumn{3}{|c|}{$\begin{array}{c}\text { Compact ing, Sunterang, Pressang \& } \\
\text { Anneal ing Data }\end{array}$} & \multirow{2}{*}{$\mid \begin{array}{l}\text { Density } \\
\text { (gmas/cc) }\end{array}$} & \multirow{2}{*}{$\begin{array}{c}\text { Grain Size (Avg Dia. } \\
\text { in mim) }\end{array}$} & \multicolumn{4}{|c|}{$\begin{array}{l}\text { Approx. } S_{1 z e} \text { "as fabr1- } \\
\text { cated, " (1n) (3) }\end{array}$} & \multirow{2}{*}{ Remarks } \\
\hline & & \begin{tabular}{|c|} 
Conpacting is \\
Sinter ang
\end{tabular} & Pressing & Annea14ng & & & $w$ & T & D & $\mathbf{L}$ & \\
\hline $\begin{array}{c}\mathrm{U} .34 \\
A, B, C \& E\end{array}$ & $\begin{array}{l}\text { Uranuum powder }<325 \\
\text { mesh cold conpacted } \\
\text { and suntered. }\end{array}$ & $\begin{array}{l}65 \mathrm{tg1}, 240 \\
\min \cdot 2 t \\
1125^{\circ} \mathrm{C} .\end{array}$ & $\cdots$ & $\cdots$ & 17.2 & $\begin{array}{l}\text { Very large \& arregu- } \\
\text { lar }(>10 \mathrm{~mm})\end{array}$ & 0.4 & 0.45 & & 10.5 & Pressure applied in thickness direction. \\
\hline $\begin{array}{l}76 \mathrm{~B} \cdot \frac{1}{2} \\
76 \mathrm{~B} \cdot 2\end{array}$ & $\begin{array}{l}\text { Uranuum powder }<325 \\
\text { mesh cold compacted, } \\
\text { sintered, repressed, } \\
\text { and arnealed. }\end{array}$ & $\begin{array}{l}65 \mathrm{tss}, 120 \\
\text { min at } \\
1095^{\circ} \mathrm{C} .\end{array}$ & $\begin{array}{l}\text { Repressed } \\
\text { at R.T.. } \\
139 \text { tsi }\end{array}$ & $\begin{array}{l}60 \min . \\
\text { at } 500^{\circ} \mathrm{C}\end{array}$ & $\begin{array}{l}16.4 \\
16.2\end{array}$ & $\begin{array}{l}\text { Very large \& arregu- } \\
\text { lar }\end{array}$ & 0.39 & 024 & & 7.0 & Pressure applied an thackness durection. \\
\hline $\begin{array}{l}168+1 \\
168-2\end{array}$ & $\begin{array}{l}\text { Uran aum posseder }<325 \\
\text { mesh. Cold conpacted, } \\
\text { sintered, repressed, } \\
\text { and annealed. }\end{array}$ & $\begin{array}{l}50 \text { tsi, } 180 \\
\text { min. at } \\
1090^{\circ} \mathrm{C} \text {. }\end{array}$ & $\begin{array}{l}\text { Repressed } \\
\text { at R.T. in } \\
3 \text { directions } \\
90^{\circ} \text { apart; } \\
100-175 \text { tsi. }\end{array}$ & $\begin{array}{l}60 \min \\
\text { at } 1090^{\circ} \mathrm{C}\end{array}$ & $\begin{array}{l}18.03 \\
18.1\end{array}$ & $\begin{array}{l}\text { Very large \& arregu- } \\
\text { lar }\end{array}$ & 105 & 0.5 & & $05^{(1)}$ & $\begin{array}{l}\text { Cubes for repressing cut fron rectangular } \\
\text { sintered plece } 6^{\mathrm{A}} \text { long. Repressed at roem } \\
\text { temperature three times on different faces } \\
\text { Direct ons of final pressing not adent if ied. }\end{array}$ \\
\hline $\begin{array}{l}509-1 \\
510-1\end{array}$ & $\begin{array}{l}\text { Urana powder }<325 \\
\text { mesh. Hot pressed. }\end{array}$ & ... & $\begin{array}{l}25-30 \text { tss. } \\
15 \text { min. at } \\
600^{\circ} \mathrm{C} \text {. }\end{array}$ & $\cdots$ & $\begin{array}{l}18.77 \\
1878\end{array}$ & $\begin{array}{l}\text { Sinall \& unx form, } \\
025 \text { or less }\end{array}$ & $\ldots$ & 03 & 1.44 & ... & Pressure applied in thickness direction \\
\hline $\begin{array}{l}611-1 \\
\text { thru } \\
611-7\end{array}$ & $\begin{array}{l}\text { Urannum powder }<325 \\
\text { mesh. Hot pressed. } \\
\text { Single pressing. }\end{array}$ & $\cdots$ & $\begin{array}{l}25 \text { tss, } 15 \\
\min \text { at } \\
570^{\circ} \mathrm{C} .\end{array}$ & ... & $\begin{array}{c}18.56 \\
\text { to } \\
1872\end{array}$ & $\begin{array}{l}\text { Small \& uns form, } \\
\text { About } 0.020 \text {. }\end{array}$ & $\ldots$ & $\ldots$ & 1.4 & 4 & $\begin{array}{l}\text { Pressure applyed in length durection of } \\
4^{n} \text { slug. }\end{array}$ \\
\hline $\begin{array}{l}571 \\
573\end{array}$ & $\begin{array}{l}\text { Urantum povder }<4 \\
\text { mooch Hot preased. }\end{array}$ & $\cdots$ & $\begin{array}{l}11 \text { tss, } 15 \\
\min \text { at } \\
600^{\circ} \mathrm{C}\end{array}$ & $\ldots$ & $\begin{array}{l}1874 \\
18.78\end{array}$ & Appros $\quad 0022^{(2)}$ & $-\cdots$ & $\cdots$ & 1.4 & 2 & $\begin{array}{l}\text { Die lubricated wath aquadag Pressure } \\
\text { applied in length direction of slug. }\end{array}$ \\
\hline $\begin{array}{l}1354 \\
1359 \\
1361\end{array}$ & $\begin{array}{l}\text { Uranum powder }<80 \\
\text { mesh. Hot pressed }\end{array}$ & $\cdots$ & $\begin{array}{l}11 \text { tsy } 15 \\
\min \text {. at } \\
600^{\circ} \mathrm{C}\end{array}$ & ... & $\begin{array}{l}18.88 \\
1886 \\
18.90\end{array}$ & $\begin{array}{l}<0.01 \\
0.012 \text { to } 00.01 \\
0.017 \text { to }<0.01\end{array}$ & $\ldots$ & $\cdots$ & 12 & 4 & $\begin{array}{l}\text { Die lubricant used, no sleeve. Pressure } \\
\text { applyed in length drectron of slug. }\end{array}$ \\
\hline $\begin{array}{l}1358 \\
1380 \\
1392\end{array}$ & $\begin{array}{l}\text { Uranium powder }<80 \\
\text { mesh. Hot pressed. }\end{array}$ & $\cdots$ & $\begin{array}{l}11 \text { tss } 15 \\
\min \text { at } \\
600^{\circ} \mathrm{C}\end{array}$ & $\ldots$ & $\begin{array}{l}18.89 \\
18.91 \\
1892\end{array}$ & $<0 \quad 01$ & $\ldots$ & $\cdots$ & 1.2 & 4 & $\begin{array}{l}\text { Die lubricant used, no sleeve. Pressure } \\
\text { applied in length direction of slug }\end{array}$ \\
\hline $\begin{array}{l}645 \\
651\end{array}$ & $\begin{array}{l}\text { Uranium powder }<4 \\
\text { mesh. Hot pressed } \\
\text { and repressed. }\end{array}$ & $\cdots$ & $\begin{array}{l}10 \mathrm{tsi}, 15 \\
\min \text { at } \\
600^{\circ} \mathrm{C}, 2 \\
\text { pressings. }\end{array}$ & $\cdots$ & $\begin{array}{l}18.75 \\
1881\end{array}$ & $\cdots$ & $\cdots$ & $\cdots$ & 13 & 4 & $\begin{array}{l}\text { Graphite sleeve used and da. Pressure } \\
\text { applised in length direction of slug. }\end{array}$ \\
\hline
\end{tabular}

(1) Dimensions of dubes cut from sintered plate which was $0.5^{n}$ wide $x 08^{n}$ thick $x 6^{n}$ long "as sintered

(2) Frons haxdness vs gran size telationship (SEP 72 - Reference 2).

W - width, T - thickness, D - dis aneter, $L$ - length

(4) Fabrication data supplied by Sylvanı 


\section{0 \\ Table II}

FABRICATION DATA OF SPECIMENS MADE DIPECTLY FROM URANILM HYDHIDE POWDERS (4)

\begin{tabular}{|c|c|c|c|c|c|c|c|c|c|c|c|}
\hline \multirow{2}{*}{$\begin{array}{l}\text { Specimen } \\
\text { No. }\end{array}$} & \multirow{2}{*}{$\begin{array}{l}\text { Raw Materials and } \\
\text { Fabrication Mothods }\end{array}$} & \multicolumn{3}{|c|}{$\begin{array}{c}\text { Compacting, Sintering, Pressing } \\
\text { Annealing Data } \\
\end{array}$} & \multirow{2}{*}{$\begin{array}{l}\text { Density } \\
\text { (gms/ce) }\end{array}$} & \multirow{2}{*}{$\begin{array}{l}\text { Grain Size (Avg. } \\
\text { Dia. in } \operatorname{mm} \text { ) }\end{array}$} & \multicolumn{4}{|c|}{$\begin{array}{l}\text { Approx. Size "as fab- } \\
\text { ricated" (in.) (3) }\end{array}$} & \multirow{2}{*}{ Remarks } \\
\hline & & $\begin{array}{c}\text { Compacting \& } \\
\text { Sintering }\end{array}$ & Pressing & Annealing & & & $w$ & $\mathbf{T}$ & D & I & \\
\hline $\begin{array}{l}625-1 \\
625-2 \\
634-1 \\
634-2\end{array}$ & $\begin{array}{l}\text { Uranium hydride pow- } \\
\text { der }<325 \text { mesh. Hot } \\
\text { pressed. }\end{array}$ & $\infty$ & $\begin{array}{l}10 \text { tsi; } 15 \mathrm{~min} . \\
\text { at } 600^{\circ} \mathrm{C} \text {. } \\
5 \text { tsi; } 15 \mathrm{~min} . \\
\text { at } 600^{\circ} \mathrm{C} .\end{array}$ & $\cdots$ & $\begin{array}{l}18.81 \\
18.84\end{array}$ & $\begin{array}{l}\text { Small a uniform; } \\
<0.01 \mathrm{~mm} \text {. }\end{array}$ & $\cdots$ & 0.3 & $1-3 / 8$ & $\ldots$ & $\begin{array}{l}\text { Pressure applied in thickness } \\
\text { direction. }\end{array}$ \\
\hline 674 & $\begin{array}{l}\text { Uranium hydride pow- } \\
\text { der }<10 \text { microns. Hot } \\
\text { pressed. }\end{array}$ & $\cdots$ & $\begin{array}{l}11 \text { tsi ; } 15 \mathrm{~min} . \\
\text { at } 600^{\circ} \mathrm{C} .\end{array}$ & $\cdots$ & 18.84 & Approx. $0.01^{(2)}$ & $\cdots$ & $\cdots$ & 1.4 & 2 & $\begin{array}{l}\text { Die lubricant with aquadag. } \\
\text { Pressure applied in length } \\
\text { direction of slug. }\end{array}$ \\
\hline $\begin{array}{l}25 \\
26 \\
31\end{array}$ & $\begin{array}{l}\text { Uranium hydride pow- } \\
\text { der; } 10 \text { microns and } \\
\text { less. Hot pressed. }\end{array}$ & $\infty$ & $\begin{array}{l}11 \mathrm{tsi} ; 10 \mathrm{~min} . \\
\text { at } 600^{\circ} \mathrm{C} .\end{array}$ & $\cdots$ & $\begin{array}{l}18.89 \\
18.86 \\
18.85\end{array}$ & $<0.01$ & $\cdots$ & $\cdots$ & 1.3 & 4 & $\begin{array}{l}\text { Die lubricant used; no sleeve. } \\
\text { Pressure applied in length } \\
\text { direction of slug. }\end{array}$ \\
\hline $\begin{array}{l}35 \\
36 \\
48\end{array}$ & $\begin{array}{l}\text { Uranium hydride powe } \\
\text { der; } 10 \text { microns and } \\
\text { less. Hot pressed. }\end{array}$ & $\cdots$ & $\begin{array}{l}11 \text { tsi; } 10 \mathrm{~min} . \\
\text { at } 600^{\circ} \mathrm{C} \text {. }\end{array}$ & $\ldots$ & $\begin{array}{l}18.89 \\
18.91 \\
18.92\end{array}$ & $<0.01$ & $\cdots$ & $\cdots$ & 1.3 & 4 & $\begin{array}{l}\text { Die lubrican used; no sleeve. } \\
\text { Pressing in length direction. }\end{array}$ \\
\hline 680 & $\begin{array}{l}\text { Uranium hydride pow- } \\
\text { der: } 10 \text { snicrons or } \\
\text { less. Sinterwelded } \\
\text { from } 2 \text { prior hot } \\
\text { pressed } 2 \text {-inch } \\
\text { slugs }(2)\end{array}$ & $\cdots$ & $\begin{array}{l}10 \mathrm{tsi} ; 15 \mathrm{~min} . \\
\text { at } 619-642^{\circ} \mathrm{C} \text { : } \\
\text { for sinterwe ld - } \\
\text { ing: } 20 \mathrm{tsi} \mathrm{s} \\
\min \text { at } 645^{\circ} \mathrm{C} \text {. }\end{array}$ & $\ldots$ & 18.90 & 0.025 to $<0.01$ & $\cdots$ & $\cdots$ & 1.3 & 4 & $\begin{array}{l}\text { Die lubricant used; no sleeve. } \\
\text { Pressing in length direction. }\end{array}$ \\
\hline 696 & $\begin{array}{l}\text { Urani um hydride pow- } \\
\text { der; } 10 \text { microns or } \\
\text { less. Sinterwelded } \\
\text { from } 4 \text { prior hot } \\
\text { pressed } 2 \text {-inch slugs. }\end{array}$ & $\ldots$ & $\begin{array}{l}11 \text { tsi } 15 \text { min. } \\
\text { at } 624-636^{\circ} \mathrm{C} \text {; } \\
\text { same for sinter } \\
\text { welding. }\end{array}$ & $\cdots$ & 18.92 & Argprox. $0.02^{(1)}$ & $\ldots$ & $\ldots$ & 1.3 & 8 & $\begin{array}{l}\text { Die lubricant used; no sleeve. } \\
\text { Pressing in length divection. }\end{array}$ \\
\hline
\end{tabular}

(1) From hardness vs. grain size relationship (SEP 72 - Reference 2).

(2) Sinterwelding consisted of placing approximately 25 gms of $\mathrm{UH}_{3}$ between the components and hot pressing at $600-650^{\circ} \mathrm{C}$.

(3) W - width; $T$ - thickness; D - diameter; $L$ - length.

(4) Fabrication data supplied by Sylvania. 


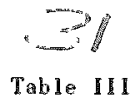

THERMAL CYCLING DATA OF SPECIMENS MADE FHOM URANIUM POWDERS

\begin{tabular}{|c|c|c|c|c|c|c|c|c|c|c|c|}
\hline \multirow{2}{*}{$\begin{array}{l}\text { Specìnen } \\
\text { No. }\end{array}$} & \multicolumn{4}{|c|}{$\begin{array}{c}\text { Initial Dimensions }(1) \\
\text { (inches) }\end{array}$} & \multirow{2}{*}{$\begin{array}{l}\text { Type } \\
\text { Cycle }\end{array}$} & \multirow{2}{*}{$\begin{array}{l}\text { No. of } \\
\text { Cycles }\end{array}$} & \multicolumn{4}{|c|}{$\begin{array}{c}\text { Dimensional Changs } \\
\text { Upon Cyeling }(\%)\end{array}$} & \multirow[t]{2}{*}{ Remarks } \\
\hline & 霍ideb & Thickness & Dimerer & Length & & & Width & Thickness & Diamet ex & Length & \\
\hline $\begin{array}{l}U * 34 A \\
U-34 B \\
U-34 C \\
U-34 E\end{array}$ & $\begin{array}{l}0.4325 \\
0.4348 \\
0.4328 \\
0.4298\end{array}$ & $\begin{array}{l}0.3400 \\
0.3343 \\
0.3324 \\
0.3322\end{array}$ & & $\begin{array}{l}1.7371 \\
1.6979 \\
1.6854 \\
1.6665\end{array}$ & $\begin{array}{l}\text { Woosher } \\
\text { Woosher } \\
\text { Woosher } \\
\text { Woosher }\end{array}$ & $\begin{array}{r}50 \\
100 \\
150 \\
50 \\
100 \\
150 \\
50 \\
100 \\
150 \\
50 \\
100 \\
150\end{array}$ & $\begin{array}{l}+0.60 \\
+1.21 \\
+4.21 \\
+0.23 \\
+0.34 \\
+0.85 \\
+0.53 \\
+1.25 \\
+0.69 \\
+0.55 \\
+1.60 \\
+2.58\end{array}$ & $\begin{array}{r}+7.70 \\
+5.88 \\
+12.4 \\
+1.08 \\
+2.24 \\
+3.83 \\
+0.21 \\
+0.63 \\
+0.63 \\
+0.659 \\
+1.69 \\
\mathrm{Ni1}\end{array}$ & & $\begin{array}{c}N i 1 \\
N i 1 \\
+0.41 \\
+0.44 \\
+0.71 \\
+0.61 \\
N i 1 \\
+0.10 \\
-0.23 \\
-0.017 \\
-0.26\end{array}$ & 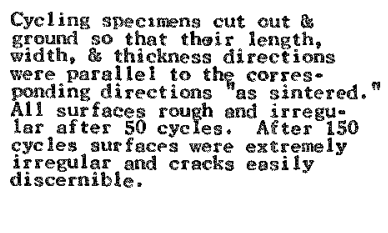 \\
\hline $\begin{array}{l}76 \mathrm{~B}-1 \\
76 \mathrm{~B}-2\end{array}$ & $\begin{array}{l}0.3670 \\
0.3460\end{array}$ & $\begin{array}{l}0.2300 \\
0.2057\end{array}$ & & $\begin{array}{l}1.6654 \\
1.6771\end{array}$ & $\begin{array}{l}\text { Woosher } \\
\text { Woosher }\end{array}$ & $\begin{array}{l}100 \\
200 \\
400 \\
500 \\
100 \\
200 \\
400 \\
500\end{array}$ & $\begin{array}{r}+0.87 \\
+1.66 \\
+3.27 \\
+5.20 \\
+1.10 \\
+1.88 \\
+3.21 \\
+4.77\end{array}$ & $\begin{array}{r}+1.26 \\
+2.09 \\
+3.56 \\
+4.96 \\
+1.51 \\
+2.53 \\
+3.45 \\
+5.88\end{array}$ & & $\begin{array}{l}40.95 \\
+1.98 \\
+3.69 \\
+5.27 \\
+1.02 \\
+2.41 \\
+4.01 \\
+5.60\end{array}$ & $\begin{array}{l}\text { Deep surface cracks. S1ight } \\
\text { bow in specimens afieg too } \\
\text { cyeles. Surface roughening } \\
\text { slight Repressing direetion } \\
\text { represented by thickness dimen - } \\
\text { sion of cycling specimens. }\end{array}$ \\
\hline $\begin{array}{l}168+1 \\
168-2\end{array}$ & 0.4850 & 0.4478 & & 0.4993 & $\begin{array}{l}\text { Woosher } \\
\text { Woosher }\end{array}$ & $\begin{array}{l}100 \\
200 \\
100 \\
200\end{array}$ & $\begin{array}{r}+2.06 \\
+3.71 \\
+1.95 \\
+8.38\end{array}$ & $\begin{array}{r}+2.72 \\
+4.30 \\
+1.69 \\
+3.04\end{array}$ & & $\begin{array}{l}+1.34 \\
+1.54 \\
+1.55 \\
+2.38\end{array}$ & $\begin{array}{l}\text { Surface roughening pronounced } \\
\text { after } 100 \text { cycles. Directions } \\
\text { arbitrartiy assigned with re* } \\
\text { spect to pressing direction. }\end{array}$ \\
\hline $\begin{array}{l}509-1 \\
510-1\end{array}$ & $\begin{array}{l}0.3103 \\
0.2500\end{array}$ & $\begin{array}{l}0.1717 \\
0.1748\end{array}$ & & $\begin{array}{l}1.0349 \\
1.1098\end{array}$ & $\begin{array}{l}\text { Woosher } \\
\text { woosher }\end{array}$ & $\begin{array}{l}100 \\
200 \\
300 \\
500 \\
100 \\
200 \\
300 \\
500\end{array}$ & $\begin{array}{r}+1.2 \\
+1.6 \\
+1.5 \\
+1.2 \\
+0.3 \\
+0.8 \\
+0.9 \\
+1.6\end{array}$ & $\begin{array}{l}N i 1 \\
-0.7 \\
-1.44 \\
-2.6 \\
-0.4 \\
-1.4 \\
-1.0 \\
-1.4\end{array}$ & & $\begin{array}{l}+0.5 \\
+0.7 \\
+0.9 \\
+1.2 \\
+0.3 \\
+0.4 \\
+0.7 \\
+1.5\end{array}$ & $\begin{array}{l}\text { Slight warg. slight "wire edge" } \\
\text { effoct. Roughening gight. } \\
\text { Thiekness dimention regresents } \\
\text { pressing direstion. }\end{array}$ \\
\hline $509-1 a^{(2)}$ & $\begin{array}{l}0.2952 \\
0.2441\end{array}$ & $\begin{array}{l}0.1478 \\
0.1631\end{array}$ & & $\begin{array}{l}0.7882 \\
0.8536\end{array}$ & $\begin{array}{l}\text { Woosher } \\
\text { woosher }\end{array}$ & $\begin{array}{l}100 \\
200 \\
300 \\
500 \\
100 \\
200 \\
300 \\
\mathbf{5 0 0}\end{array}$ & $\begin{array}{l}+0.3 \\
40.3 \\
40.3 \\
\mathrm{Ni1} \\
\mathrm{Ni1} \\
-0.4 \\
-0.5 \\
-1.1\end{array}$ & $\begin{array}{r}+0.7 \\
+1.4 \\
+1.7 \\
+1.5 \\
-0.8 \\
-0.4 \\
-0.3 \\
-0.4\end{array}$ & & $\begin{array}{l}+0.3 \\
+0.4 \\
+0.5 \\
+0.5 \\
+0.4 \\
+0.6 \\
+0.7 \\
+0.9\end{array}$ & $\begin{array}{l}\text { S1ight wire edge and warp. } \\
\text { Roughening more pronounsed. }\end{array}$ \\
\hline $\begin{array}{l}611-1 \\
611-4 \\
611-7 \\
611-2 \\
611-3 \\
611-5 \\
611-6\end{array}$ & $\begin{array}{l}0.1242 \\
0.1236 \\
0.1236 \\
0.1233 \\
0.1247 \\
0.1258 \\
0.1226\end{array}$ & $\begin{array}{l}0.1247 \\
0.1250 \\
0.1253 \\
0.1251 \\
0.1247 \\
0.1251 \\
0.1249\end{array}$ & & $\begin{array}{l}1.1242 \\
1.128 \\
1.1251 \\
1.1239 \\
1.1228 \\
1.1251 \\
1.1250\end{array}$ & $\begin{array}{l}\text { Woosher } \\
\text { Woosher } \\
\text { Woosher } \\
\text { Woosher } \\
\text { Woosher } \\
\text { Woosher } \\
\text { Woosher }\end{array}$ & $\begin{array}{l}500 \\
500 \\
500 \\
500 \\
500 \\
500 \\
\mathbf{5 0 0}\end{array}$ & $\begin{array}{r}+2.6 \\
+2.4 \\
+2.8 \\
+1.8 \\
+2.2 \\
+2.4 \\
+2.7\end{array}$ & $\begin{array}{r}-1.1 \\
-1.2 \\
-0.9 \\
+2.2 \\
+2.0 \\
+1.9 \\
+2.4\end{array}$ & & $\begin{array}{r}+2.8 \\
+3.4 \\
+2.6 \\
-1.0 \\
-1.5 \\
-1.2 \\
-1.2\end{array}$ & 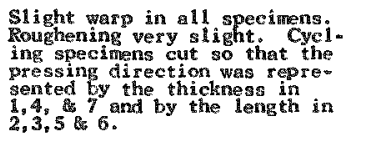 \\
\hline 671 & & & $\begin{array}{l}1.4385 \\
1.4472\end{array}$ & $\begin{array}{l}2.0778 \\
2.0760\end{array}$ & $\begin{array}{l}\text { Induct: } \\
\text { Induet }\end{array}$ & $\begin{array}{l}250 \\
250\end{array}$ & & & +0.24 to 0.52 & $\begin{array}{l}-0.81 \\
-0.52\end{array}$ & 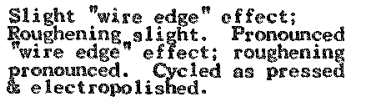 \\
\hline $\begin{array}{l}1354 \\
1359 \\
1361\end{array}$ & & & $\begin{array}{l}1.365 \\
1.364 \\
1.365\end{array}$ & $\begin{array}{l}4.089 \\
4.082 \\
4.085\end{array}$ & $\begin{array}{l}\text { Induct. } \\
\text { Induet. } \\
\text { Induct. }\end{array}$ & $\begin{array}{l}250 \\
250 \\
700 \\
750\end{array}$ & & & $\begin{array}{l}+0.22 \\
+0.38 \\
+0.73 \\
+0.07\end{array}$ & $\begin{array}{l}-0.29 \\
-0.37 \\
-0.88 \\
-0.17\end{array}$ & $\begin{array}{l}\text { S1 ight wire edges. Roughening - } \\
\text { none. }\end{array}$ \\
\hline $\begin{array}{l}1358 \\
1380 \\
1392 \\
1392\end{array}$ & & & $\begin{array}{l}1.352 \\
1.352 \\
1.352 \\
1.352\end{array}$ & $\begin{array}{l}4.010 \\
4.013 \\
4.015 \\
4.015\end{array}$ & $\begin{array}{l}\text { Induet. } \\
\text { Induct: } \\
\text { Induet. } \\
\text { Induet. }\end{array}$ & $\begin{array}{l}250 \\
250 \\
250 \\
700\end{array}$ & & & $\begin{array}{l}+0.22 \\
+0.37 \\
40.37 \\
+1.33\end{array}$ & $\begin{array}{l}-0.30 \\
-0.30 \\
-0.52 \\
-1.19\end{array}$ & 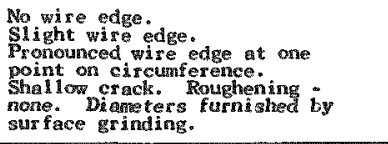 \\
\hline $\begin{array}{l}645 \\
651\end{array}$ & & & $\begin{array}{l}1.2292 \\
1.2878\end{array}$ & $\begin{array}{l}3.8950 \\
4.000\end{array}$ & $\begin{array}{l}\text { Induet. } \\
\text { Induet. }\end{array}$ & $\begin{array}{l}250 \\
250\end{array}$ & & & $\begin{array}{l}+0.14 \text { to } 0.91 \\
+0.25 \text { to } 7.65\end{array}$ & $\begin{array}{l}-0.39 \\
-1.32\end{array}$ & $\begin{array}{l}\text { Shall low ci rcunfferential crevices. } \\
\text { Roughening pronounced } \\
\text { Two deep ci rcumferential } \\
\text { crevices. Silight roughening. }\end{array}$ \\
\hline
\end{tabular}

(1) Dimensions of cycling specimens. Surfaces finished ground except as indicated.

(2) Specimens $509-1$ and $510-1$ beta rreated ( 4 min. at $725^{\circ} \mathrm{C}$ - water quenched). 
TYCLING DATA OF SPECIMENS MADE FRON UH 3 POWDERS

\begin{tabular}{|c|c|c|c|c|c|c|c|c|c|c|c|}
\hline \multirow{2}{*}{$\begin{array}{l}\text { Specimen } \\
\text { No. }\end{array}$} & \multicolumn{4}{|c|}{$\begin{array}{c}\text { Initial Dimensions (1) } \\
\text { (inches) }\end{array}$} & \multirow{2}{*}{$\begin{array}{l}\text { Cycle } \\
\text { Type }\end{array}$} & \multirow{2}{*}{$\begin{array}{l}\text { No. of } \\
\text { Cycles }\end{array}$} & \multicolumn{4}{|c|}{$\begin{array}{l}\text { Dimens ional Changes } \\
\text { Upon Cycling (\%) }\end{array}$} & \multirow{2}{*}{ Remarks } \\
\hline & Width & Thickness & Diameter & Length & & & midth & Thickness & Di ame ter & Length & \\
\hline $\begin{array}{l}625-2 \\
634-1 \\
634-2\end{array}$ & $\begin{array}{l}0.2505 \\
0.2427 \\
0.3014 \\
0.2662\end{array}$ & $\begin{array}{l}0.2518 \\
0.1516 \\
0.2862 \\
0.2438\end{array}$ & & $\begin{array}{l}1.2236 \\
1.2991 \\
1.1965 \\
1.1952\end{array}$ & $\begin{array}{l}\text { Woosher } \\
\text { Woosher } \\
\text { Woosher } \\
\text { Woosher }\end{array}$ & $\begin{array}{l}100 \\
200 \\
400 \\
500 \\
100 \\
200 \\
400 \\
500 \\
250 \\
500 \\
250 \\
500\end{array}$ & $\begin{array}{l}+0.92 \\
+0.92 \\
-0.20 \\
-0.20 \\
+0.74 \\
-0.54 \\
-0.29 \\
-0.29 \\
+0.26 \\
+1.2 \\
+1.8 \\
+0.7\end{array}$ & $\begin{array}{l}-0.32 \\
+0.36 \\
+1.5 \\
+2.4 \\
-0.02 \\
+0.01 \\
+0.03 \\
+0.52 \\
+2.3 \\
+3.4 \\
+0.49 \\
+0.9\end{array}$ & & $\begin{array}{l}-0.38 \\
-0.35 \\
-0.52 \\
-0.58 \\
\mathrm{Ni} 1 \\
+0.13 \\
+0.70 \\
+0.84 \\
-0.71 \\
-1.8 \\
-0.44 \\
-0.52\end{array}$ & $\begin{array}{l}\text { Slight wire edges; rough- } \\
\text { ness on thickness faces; } \\
\text { other faces relatively } \\
\text { smooth. Fressing direction } \\
\text { represented by either thick- } \\
\text { ness or width dimension. }\end{array}$ \\
\hline 674 & & & 1.449 & 2.0065 & Induct. & 250 & & & $\begin{array}{l}.0 .27 \text { to } \\
+0.96\end{array}$ & +0.88 & $\begin{array}{l}\text { No wire edges. Roughening - } \\
\text { none. Cycles "as pressed } \\
\text { and electropolished." }\end{array}$ \\
\hline $\begin{array}{l}25 \\
26 \\
31\end{array}$ & & & $\begin{array}{l}1.365 \\
1.366 \\
1.367\end{array}$ & $\begin{array}{l}4.135 \\
4.139 \\
4.082\end{array}$ & $\begin{array}{l}\text { Induct. } \\
\text { Induct. } \\
\text { Induet. }\end{array}$ & $\begin{array}{l}250 \\
250 \\
700 \\
250\end{array}$ & & & $\begin{array}{l}+0.15 \\
+0.15 \\
+1.24 \\
+0.07\end{array}$ & $\begin{array}{l}-0.36 \\
-0.65 \\
-1.67 \\
-0.42\end{array}$ & $\begin{array}{l}\text { No wire edges. No roughen- } \\
\text { ing. Cycled "as pressed } \\
\text { and electropol ished." }\end{array}$ \\
\hline $\begin{array}{l}35 \\
36 \\
48\end{array}$ & & & $\begin{array}{l}1.352 \\
1.352 \\
1.352\end{array}$ & $\begin{array}{l}4.012 \\
4.013 \\
4.012\end{array}$ & $\begin{array}{l}\text { Induct. } \\
\text { Induct. } \\
\text { Induct. }\end{array}$ & $\begin{array}{l}250 \\
250 \\
250 \\
700\end{array}$ & & & $\begin{array}{l}+0.33 \\
+0.33 \\
+0.63 \\
+1.18\end{array}$ & $\begin{array}{l}-0.47 \\
-0.46 \\
-0.85 \\
-1.62\end{array}$ & $\begin{array}{l}\text { No wire edges. No roughen- } \\
\text { ing. }\end{array}$ \\
\hline 680 & & & 1.4292 & 4.0852 & Induct. & 250 & & & $\begin{array}{l}-0.54 \text { to } \\
+0.41\end{array}$ & +0.15 & $\begin{array}{l}\text { Roughening s light; pro- } \\
\text { nounced wire edge marks } \\
\text { at weld; scattered small } \\
\text { hair-line surface cracks. }\end{array}$ \\
\hline 696 & & & 0.7488 & 7.955 & Induct. & 700 & & & +0.66 & +0.40 & $\begin{array}{l}\text { Roughening-none; marks at } \\
\text { weld visible; diameter out } \\
\text { of round and wavy. }\end{array}$ \\
\hline
\end{tabular}

(1) Dimensions of cycling specimens. Surfaces finished ground except as indicated. 